'ФГБНУ «Научноисследовательский институт ревматологии им. В.А. Насоновой» 115522, Российская Федерация, Москва, Каширское шоссе, 34а ФГАОУ ВО «ПервыЙ Московский государственный медицинский университет имени И.М. Сеченова» Минздрава России (Сеченовский Университет) 119991, Российская Федерация, Москва, ул. Трубецкая, 8, стр. 2 ${ }^{3}$ ФБОУ ДПО «Российская медицинская академия непрерывного просрессионального образования» Минздрава России 125993, Российская Федерация, Москва, ул. Баррикадная, 2/1, стр. 1

IV.A. Nasonova Research Institute of Rheumatology 115522, Russian Federation, Moscow, Kashirskoye Highway, 34A

2.M. Sechenov First Moscow State Medical University of the Ministry of Health Care of Russian Federation (Sechenov University) 119991, Russian Federation, Moscow, Trubetskaya str., 8, building 2

${ }^{3}$ Russian Medical Academy of Continuous Professional Education of the Ministry of Healthcare of the Russian Federation 125993, Russian Federation, Moscow, Barrikadnaya str., 2/1, building 1

Контакты: Насонов Евгений Львович, nasonov@irramn.ru Contacts: Evgeny Nasonov, nasonov@ irramn.ru

Поступила 14.12.2021 Принята 21.12.2021

K 60-летию журнала

«Научно-практическая ревматология» Достижения ревматологии в начале XXI века

\author{
Е.Л. Насонов ${ }^{1,2}$, А.М. Лила' ${ }^{1,3}$, Т.В. Дубинина', О.А. Никитинская', В.Н. Амирджанова' \\ по поручению редакционной коллегии журнала «Научно-практическая ревматология»
}

В 2022 году журнал «Научно-практическая ревматология» отмечает 60-летний юбилей. В статье представлены материалы, касающиеся истории создания журнала и наиболее важных публикаций, представленных на его страницах за последние годы, в том числе обзор российских и международных исследований по фармакотерапии иммуновоспалительных ревматических заболеваний (ИВРЗ), проблемам ревматоидного артрита, системной красной волчанки, российскому опыту применения биоаналогов генно-инженерных биологических препаратов для лечения ИВРЗ, ревматологическим аспектам коронавирусной болезни 2019 и другим проблемам вопросам.

Ключевые слова: иммуновоспалительные ревматические заболевания, ревматоидный артрит, системная красная волчанка, коронавирусная болезнь 2019

Для цитирования: Насонов ЕЛ, Лила АМ, Дубинина ТВ, Никитинская ОА по поручению редакционной коллегии журнала «Научно-практическая ревматология». Достижения ревматологии в начале XXI века. Научно-практическая ревматология. 2022;60(1):5-20.

\title{
ADVANCES IN RHEUMATOLOGY AT THE BEGINNING OF THE 21ST CENTURY
}

Evgeny L. Nasonov ${ }^{1,2}$, Alexander M. Lila ${ }^{1,3}$, Tatiana V. Dubinina ${ }^{1}$, Oksana A. Nikininskaya ${ }^{1}$, Vera N. Amirdjanova ${ }^{1}$ on behalf of the editorial board of the journal "Rheumatology Science and Practice"

В 2022 году журнал «Научно-практическая ревматология» отмечает 60-летний юбилей. В статье представлены материалы, касающиеся истории создания журнала и наиболее важных публикаций, представленных на его страницах за последние годы, в том числе обзор российских и международных исследований по фармакотерапии иммуновоспалительных ревматических заболеваний (ИВРЗ), проблемам ревматоидного артрита, системной красной волчанки, российскому опыту применения биоаналогов генно-инженерных биологических препаратов для лечения ИВРЗ, ревматологическим аспектам коронавирусной болезни 2019 и другим проблемам вопросам.

Ключевые слова: иммуновоспалительные ревматические заболевания, ревматоидный артрит, системная красная волчанка, коронавирусная болезнь 2019

For citation: Nasonov EL, Lila AM, Dubinina TV, Nikininskaya OA on behalf of the editorial board of the journal "Rheumatology Science and Practice". Advances in rheumatology at the beginning of the 21st century. NauchcnoPrakticheskaya Revmatologia = Rheumatology Science and Practice. 2022;60(1):5-20 (In Russ.).

doi: 10.47360/1995-4484-2022-5-20

Ревматология - одна из наиболее бурно развивающихся медицинских специальностей, которая эффективно адаптирует достижения и вносит вклад в прогресс мировой фундаментальной и клинической медицинской науки [1]. В основе патогенеза иммуновоспалительных ревматических заболеваний (ИВРЗ) лежит сложное сочетание генетически детерминированных и приобретенных дефектов иммунорегуляторных механизмов, ограничивающих патологическую активацию иммунной системы в ответ на потенциально патогенные факторы внешней среды. Такие ИВРЗ, как ревматоидный артрит (PA) и системная красная волчанка (СКВ), не только наиболее тяжелые хронические воспалительные заболевания человека, но и «модели» для изучения фундаментальных механизмов патогенеза и подходов к фармакотерапии других заболеваний, связанных с развитием аутоиммунитета и/или аутовоспаления. Актуальность проблемы ИВРЗ для современной медицины определяется их высокой распространенностью в популяции, трудностью ранней диагностики, быстрым развитием инвалидности и неблагоприятным жизненным прогнозом. Высокий риск преждевременной летальности связан не только с «тяжестью» самого воспалительного процесса, но и с развитием широкого спектра коморбидных состояний [2], включая атеросклеротическое поражение сосудов и артериальную гипертензию [3, 4], интерстициальное заболевание легких [5], метаболический синдром [6] и многих других. Все это вместе взятое делает ревматологию уникальной специальностью, находящейся на стыке терапии и иммунологии.

$$
\text { В } 2022 \text { году исполняется }
$$
60 лет журналу «Научно-практическая ревматология», учредителями которого являются Общероссийская общественная организация «Ассоциация ревматологов России» и ФГБНУ НИИР им. В.А. Насоновой. «Научно- 

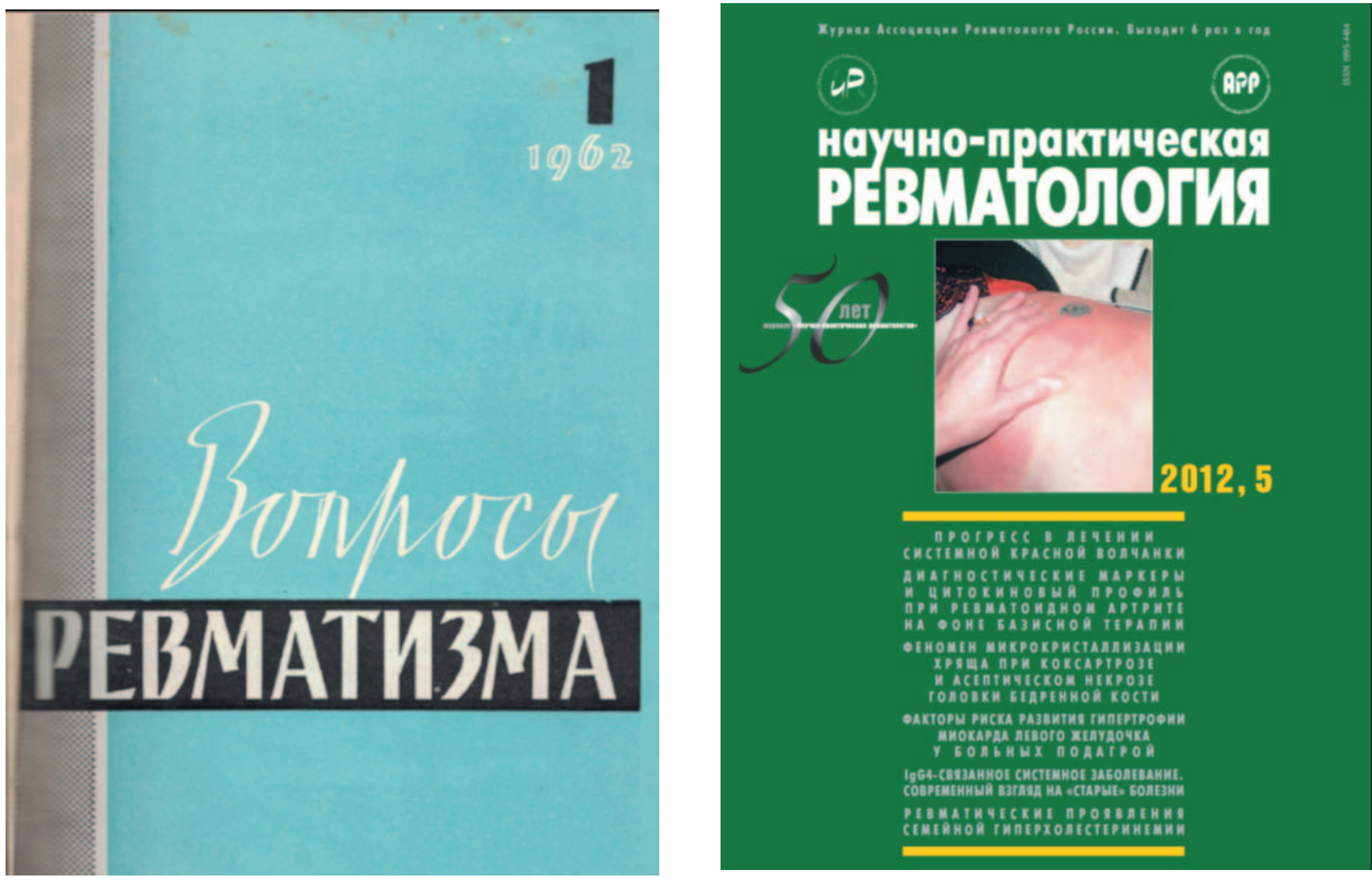

Рис. 1. Обложки журнала «Научно-практическая ревматология»

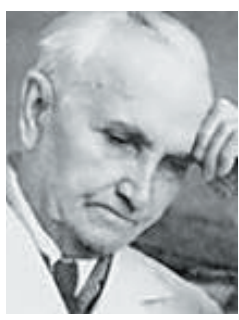

А.И. Нестеров

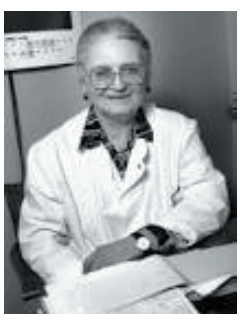

B.А. Насонова

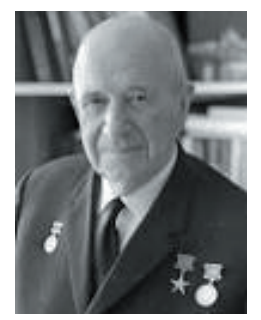

E.M. Тареeв

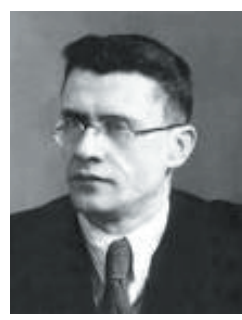

А.Д. Адо

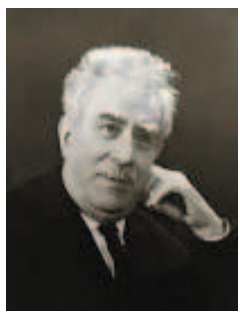

В.И. Иофффe

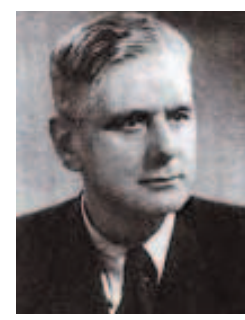

М.А. Ясиновский

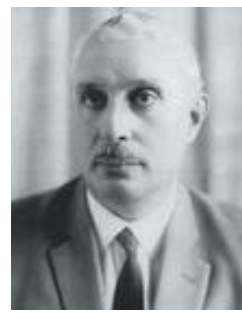

П.Н. Юренев

Рис 2. Фотографии членов редколлегии журнала «Вопросы ревматизма»

практическая ревматология» - полноправный преемник журнала «Вопросы ревматизма», который начал издаваться с 1962 г. по инициативе одного из основоположников российской ревматологии академика А.И. Нестерова. В течение многих лет главным редактором журнала была академик В.А. Насонова, а в редакционную коллегию в разное время входили выдающиеся врачи и ученые нашей страны: академики Е.М. Тареев (терапия), А.Д. Адо (аллергология, иммунология), В.И. Иоффе (микробиология, иммунология), М.А. Ясиновский (терапия), П.Н. Юренев (терапия), профессора В.В. Михеев (неврология), А.А. Тустановский (биохимия), В.А. Сачков (аллергология, иммунология), М.Г. Астапенко (ревматология), В.Н. Анохин (ревматология), А.В. Долгополова (педиатрия, ревматология), М.Е. Курмаева (терапия, ревматология), И.М. Лямперт (микробиология), 3.С. Алекберова (ревматология), Л.И. Беневоленская (ревматология), Н.Н. Кузьмина (ревматология, педиатрия), Э.С. Мач (ревматология), А.И. Сперанский (аллергология, иммунология), Р.М. Балабанова (ревматология) и многие другие.
С момента основания и до настоящего времени в журнале публикуются статьи ведущих ревматологов и терапевтов нашей страны, посвященные наиболее важным достижениям ревматологической науки и клинической практики. В структуре журнала традиционно присутствуют несколько разделов: «Передовая статья», «Оригинальные исследования», «Обзоры и лекции», «Клинические наблюдения», а в последние годы «Прогресс в ревматологии в XXI веке»», «Российские и международные рекомендации по лечению ревматических заболеваний», «Проблемы ревматологии в период пандемии коронавирусной болезни 2019», «Форум молодых ученых», «Педиатрическая ревматология», «Ревмоортопедия и реабилитация». В разделе «Информация» освещаются проблемы, обсуждаемые на заседаниях профильной комиссии Минздрава России по специальности «ревматология» и пленумах правления Общероссийской общественной организации «Ассоциация ревматологов России».

60-летний юбилей представляется уникальным поводом для обсуждения наиболее важных проблем

Научно-практическая ревматология. 2022;60(1):5-20 


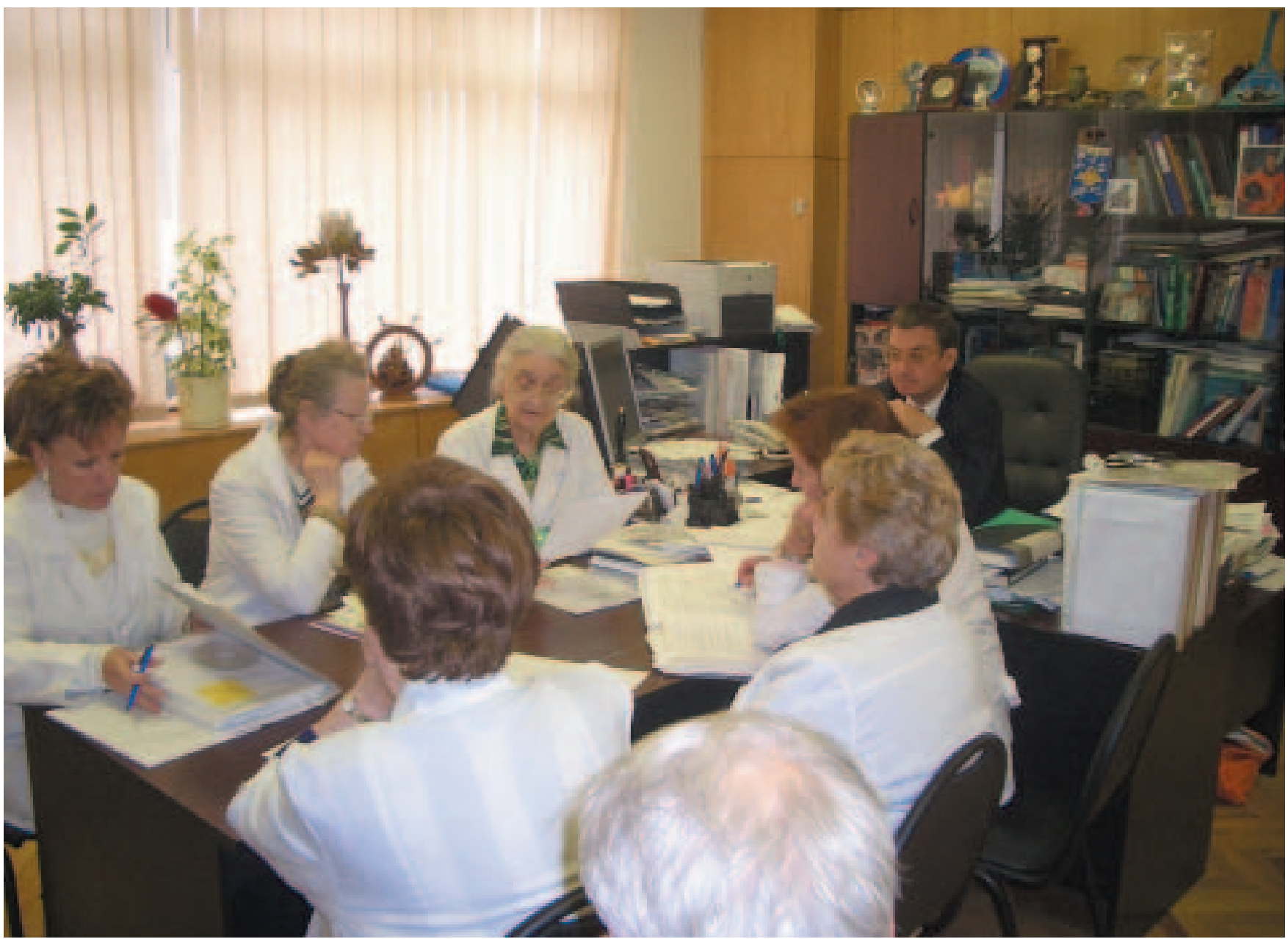

Рис. 3. Заседание редколлегии журнала «Научно-практическая ревматология (2003 г). Слева направо: В.Н. Амирджанова, Л.И. Беневоленская, В.А. Насонова (главный редактор журнала), Е.Л. Насонов

современной ревматологии, нашедших отражение на страницах журнала «Научно-практическая ревматология» за последние годы.

\section{Прогресс в ревматологии в XXI веке}

В разделе «Прогресс в ревматологии в XXI веке» была представлена серия аналитических обзоров, посвященных изучению фундаментальных механизмов патогенеза ИВРЗ [1-8] и новых лабораторных и инструментальных (УЗИ, МРТ, капилляроскопия) методов ранней диагностики, биомаркеров активности воспаления, прогноза и персонификации терапии при этих заболеваниях [9, 10]. Особое внимание было уделено проблемам фармакотерапии ИВРЗ, для лечения которых в начале XXI века специально разработано более 20 инновационных генно-инженерных биологических препаратов (ГИБП) - моноклональные антитела (мАТ) и рекомбинантные белки, блокирующие активность провоспалительных цитокинов [11], в том числе интерлейкина (ИЛ) 17 [12, 13], ИЛ-6 [14-21], ИЛ-1 [22-26], фактора некроза опухоли (ФНО) $\alpha$ [27-29], ИЛ-23 [30], ИЛ-5 [31], фактора роста нервов [32], патологическую активацию В-клеток (ритуксимаб, РТМ) [33-40] и Т-клеток (абатацепт, АБЦ) [41-43], В-клеточных цитокинов (белимумаб, БЛМ) [44-47], интерферона (ИФН) $\alpha$ (анифролумаб, АФМ) [48, 49], а в последние годы - группа синтетических «таргентных» препаратов (малые молекулы), блокирующих сигнализацию цитокинов, участвующих в развитии воспаления: ингибиторы Янус-киназы (JAK, Janus Kinase) [50] - тофацитиниб [51-53], барицитиниб [54], упадацитиниб [55]. Изучение клинических и иммунологических эффектов ГИБП позволяет не только повысить эффективность терапии ИВРЗ, включая РА, СКВ, анкилозирующий спондилит (АС), псориатический артрит (ПсА) и другие, но и получить новые данные о патогенезе этих и других иммуновоспалительных заболеваний человека.

\section{Российские и международные рекомендации по лечению ревматических заболеваний}

Специальный раздел посвящен российским и международным рекомендациям (Европейская антиревматическая лига, Американская коллегия ревматологов) по диагностике и лечению ИВР3, в том числе РА [56-62], АС [63-68], подагры [69-73], СКВ [74-77], системных васкулитов [78-82], острой ревматической лихорадки [83, 84], болезни Лайма [85], болезни Бехчета [86], IgG4-связанного заболевания [87], остеопороза [88, 89] и профилактики падений [90], а также вакцинации пациентов с ИВР3 [91], периоперационному ведению и антиревматической терапии пациентов с ревматическими заболеваниями перед тотальным эндопротезированием коленных и тазобедренных суставов [92], коронавирусной болезни 2019 (COVID-19) при иммуновоспалительных ревматических заболеваниях 
[93], профилактике и лечению кардиоваскулярных осложнений [94], рациональному применению нестероидных противовоспалительных препаратов (НПВП) [95, 96], лечению мышечно-скелетной боли [97], применению биоаналогов ГИБП в ревматологии [98].

\section{Ревматоидный артрит}

Особенно большое внимание на страницах журнала уделялось РА - «визитной карточке» современной ревматологии $[99,100]$. Согласно современной концепции «лечение до достижения цели» (“Treat-To-Target”), стратегической целью лечения РА является ремиссия заболевания, достижение которой ассоциируется со снижением риска потери трудоспособности, инвалидности и увеличением продолжительности жизни пациентов. Метотрексат (МТ) является препаратом «первой линии» лечения активного РА и основным компонентом стратегии «лечение до достижения цели» [56, 57, 59]. В рамках изучения этой проблемы было инициировано исследование «РЕМАРКА» (Российское ИсслЕдование МетотрексАта и биологических препаратов при Раннем аКтивном Артрите), результаты которого свидетельствуют о том, что раннее контролируемое лечение подкожным МТ позволяет добиться ремиссии более чем у половины пациентов и снизить потребность в назначении ГИБП [101103]. Хотя внедрение современной стратеги лечения РА и новых методов терапии привело к более высокой частоте развития ремиссии, чем это имело место в предыдущие декады, остается много теоретических и клинических проблем, касающихся как определения самого понятия «ремиссия», ее характеристики и типов, так и подходов к оптимальной тактике «симптоматической» и «патогенетической» лекарственной терапии РА на разных стадиях болезни. К ним в первую очередь относится гетерогенность патогенетических механизмов РА, что находит свое отражение в существовании широкого спектра фенотипов и эндотипов заболевания и позволяет рассматривать РА не как «одну болезнь», а как клинико-иммунологический синдром. В последние годы особое внимание привлечено к проблеме «рефрактерного» РА, который рассматривается как субтип заболевания, при котором последовательное назначение оптимальных доз МТ в комбинации с ГК и как минимум двух ГИБП с разными механизмами действия (например, ингибиторы ФНО- $\alpha$ или ИЛ-6 рецепторов и РТМ или АБЦ) не приводит к клинически значимому снижению воспалительной активности РА [99, 104, 105]. Резистентность к терапии при РА может быть связана со многими факторами, имеющими как субъективную, так и объективную природу. Для «ложной» резистентности к терапии характерно несоответствие между наличием объективных признаков воспаления и плохим самочувствием пациентов (боль, усталость), зависящее от преобладания «невоспалительных» механизмов боли (нарушение центральной сенситизации), депрессией, фибромиалгией, вторичными дегенеративными изменениями в суставах [106113]. Учитывая гетерогенность механизмов патогенеза РА на разных стадиях болезни, «резистентность» к терапии может быть связана с выбором «неправильного» препарата, не влияющего на преобладающие механизмы патогенеза, с нарушением фармакокинетики ГИБП, связанным с синтезом антилекарственных антител (АЛА). Интенсивно изучается роль генетических факторов резистентности, включая полиморфизм генов, участвующих в регуляции метаболизма МТ, генов цитокинов и эпигенетических факторов, которые могут влиять на эффективность терапии [99, 104].

\section{Системная красная волчанка}

Системная красная волчанка - прототип системной аутоиммунной патологии человека, относится к числу чрезвычайно гетерогенных заболеваний с точки зрения как клинических проявлений, так и генетической предрасположенности и механизмов патогенеза, что нередко затрудняет раннюю диагностику и не позволяет персонифицировать терапию [114]. В соответствии с концепцией «лечение до достижения цели», целью терапии является достижение состояния ремиссии (или низкой активности) как основы для предотвращения необратимого повреждения внутренних органов (в том числе связанного с коморбидной патологией). Прогресс фундаментальных исследований в области молекулярной биологии и иммунологии способствовал расшифровке механизмов иммунопатологии СКВ, что послужило теоретическим обоснованием для разработки новых подходов к фармакотерапии заболевания: блокирование альтернативных молекулярных и клеточных биологических «мишеней», участвующих в развитии воспаления и атоиммунитета (цитокины и ИФН типов I и II, компоненты комплемента); «регуляторы» иммунометаболических процессов в клетках иммунной системы; внутриклеточные сигнальные пути и факторы транскрипции, модулирующие активность цитокинов; патологическая активация В-клеток и плазматических клеток; трансплантация мезенхимальных стволовых клеток; активация Т-регуляторных (рег) клеток и многие другие $[47,114,115]$.

Важное место в лечении СКВ занимает белимумаб, представляющий собой человеческие моноклональные антитела (IgG1 $\lambda$ ) к BAFF (B cell-activating factor) и являющийся первым «таргетным» ГИБП, специально разработанным для лечения СКВ [44, 45]. Эффективность и безопасность БЛМ при СКВ у взрослых и детей, включая волчаночный нефрит $(\mathrm{BH})$, возможность комбинированной терапии с РТМ, стероид-сберегающее действие препарата, способность предотвращать необратимое поражение внутренних органов свидетельствуют о необходимости более широкого его применения в клинической практике [116-119].

Среди новых «патогенетических» мишеней для лечения СКВ особое внимание привлекает ИФН типа I, гиперпродукции которого придают фундаментальное значение в иммунопатогенезе этого заболевания [48]. Комплекс данных, полученных в процессе фундаментальных и клинических исследований, послужил основанием для разработки нового подхода к фармакотерапии СКВ, связанного с использованием моноклональных антител, блокирующих активность ИФН типа I или его рецепторов. В ряду этих препаратов особое место занимает анифролумаб, представляющий собой человеческие моноклональные антитела, блокирующие клеточные рецепторы для ИФН- $\alpha-$ IFNAR1 (Interferon Alpha And Beta Receptor Subunit 1) [49]. Данные клинических исследований АФМ свидетельствуют о том, что в арсенал фармакотерапии СКВ вошел новый эффективный препарат, разработка которого является примером беспрецедентно быстрого внедрения 
достижений фундаментальных исследований в клиническую практику как основной парадигмы трансляционной и персонифицированной медицины.

\section{Российские биоаналоги и оригинальные ГИБП. Участие в международных и российских исследованиях ГИБП}

Благодаря достижениям молекулярной биологии и биотехнологии была решена проблема широкомасштабного производства моноклональных антител и рекомбинантных белков, безопасных для введения в организм человека. Внедрение инновационных ГИБП в клиническую практику не только позволило повысить эффективность терапии и улучшить прогноз у пациентов, страдающих наиболее тяжелыми формами ИВРЗ, но и привело к кардинальному удорожанию лечения. Поэтому снижение стоимости лечения эффективными, но дорогостоящими ГИБП, а следовательно, увеличение доступности инновационной терапии у пациентов, живущих в странах с ограниченными экономическими ресурсами, является наиболее приоритетной задачей здравоохранения всех стран мира. Это задача решается благодаря разработке биоаналогов (biosimmilars) - биологических лекарственных препаратов, схожих по параметрам качества, эффективности и безопасности с референтным биологическим лекарственным препаратом в такой же лекарственной форме и имеющих идентичный способ введения [98].

В журнале впервые опубликована серия статей, посвященных эффективности и безопасности российских бионалогов ГИБП, разработанных фармацевтической компанией «БИОКАД»: Ацеллбия (биоаналог Ритуксимаба) - при РА [120-125], Нетакимаб (мАТ к ИЛ-17 А) - при ПсА [126] и АC [127], BCD-055 (биоаналог инфликсимаба) - при АС [128], - которые послужили основанием для регистрации этих препаратов в России и включения в российские клинические рекомендации.

Особый интерес представляют результаты успешных испытаний препарата Олокизумаб (фармацевтическая компания Р-ФАРМ), представляющего собой мАТ к ИЛ-6 и являющегося первым препаратом класса ингибиторов ИЛ-6, блокирующим не ИЛ-6 рецептор, а саму молекулу это важного провоспалительного цитокина [129]. В настоящее время завершилась серия крупных международных рандоминизрованных плацебо-контролируемых исследований (РПКИ) (CREDO-1, CREDO-2, CREDO-3), результаты которых опубликованы в ведущих зарубежных журналах [130-133] и в течение 2022 года будут широко представлены на станицах журнала «Научнопрактическая ревматология».

Заслуживают внимание материалы (субанализы), касающиеся вклада российских ревматологов в клинические испытания новых ГИБП в рамках международных РПКИ, в том числе секукинумаба (мАТ к ИЛ-17 А) при ПсА (исследования FUTURE 1 и FUTURE 2) [134] и AC (исследование MEASURE 1 и MEASURE 2) [135] и сарилумаба (мАТ к ИЛ-6 Р) при РА (исследование MOBILITY) [136].

\section{Проблемы ревматологии в период пандемии COVID-19}

В течение последних двух лет особое внимание ревматологов привлечено к проблеме коронавирусной болезни 2019 (COVID-19, coronavirus disease 2019), этиологически связанной с вирусом SARS-CoV-2 (severe acute respiratory syndrome coronavirus-2). Пандемия COVID-19 не только имеет огромное социальное значение, но и привлекает внимание к принципиально новым клиническим и фундаментальным проблемам иммунопатологии заболеваний человека. За время, прошедшее с начала пандемии, было проведено беспрецедентное число клинических и экспериментальных исследований, привлекших пристальное внимание к ревматологическим проблемам COVID-19. За этот период в журнале была опубликована серия статей, отражающих наиболее актуальные аспекты этой проблемы в ревматологии [19, 93, 137-149]. Уникальный опыт, накопленный в ревматологии в процессе изучения патогенетических механизмов и фармакотерапии ИВРЗ, имеет большое значение для расшифровки природы патологических процессов, лежащих в основе тяжелых, потенциально смертельных осложнений COVID-19, и совершенствования терапии, в том числе с использованием противовоспалительных препаратов, которые в течение многих лет специально разрабатывались для лечения ИВРЗ.

В статье представлен далеко не полный круг проблем, который рассматривался на страницах журнала «Научнопрактическая ревматология». Авторы выражают надежду, что и дальнейшем, аккумулируя российский и мировой опыт, журнал будет способствовать прогрессу российской ревматологии.

\section{Прозрачность исследования}

Исследование не имело спонсорской поддержки. Авторы несут полную ответственность за предоставление окончательной версии рукописи в печать.

Декларация о финансовых и других взаимоотношениях

Все авторы принимали участие в разработке концепции статьи и в написании рукописи. Окончательная версия рукописи была одобрена всеми авторами. Авторы не получали гонорар за статью.

\section{Благодарность}

Авторы выражают искреннюю признательность всем ревматологам, поддержавшим журнал своими научными публикациями.

\section{Л И TEPAT Y PA / REFERENCES}

1. Насонов ЕЛ. Достижения ревматологии в XXI веке. Научно-практическая ревматология. 2014;52(2):133140. [Nasonov EL. Achievements in rheumatology in the XXI century. Nauchcno-Prakticheskaya Revmatologia $=$ Rheumatology Science and Practice. 2014;52(2):133-140 (In Russ.)]. doi: 10.14412/1995-4484-2014-133-140

Научно-практическая ревматология. 2022;60(1):5-20

2. Гордеев АВ, Галушко ЕА, Насонов ЕЛ. Концепция мультиморбидности в ревматологической практике. Научно-практическая ревматология. 2014;52(4):362365. [Gordeev AV, Galushko EA, Nasonov EL. The concept of multimorbidity in rheumatologic practice. Nauchcno-Prakticheskaya Revmatologia = Rheumatology 
Science and Practice. 2014;52(4):362-365 (In Russ.)]. doi: 10.14412/1995-4484-2014-362-365

3. Попкова ТВ, Новикова ДС, Насонов ЕЛ. Сердечнососудистые заболевания при ревматоидном артрите: новые данные. Научно-практическая ревматология. 2016;54(2):122-128. [Popkova TV, Novikova DS, Nasonov EL. Cardiovascular diseases in rheumatoid arthritis: Latest data. Nauchcno-Prakticheskaya Revmatologia $=$ Rheumatology Science and Practice. 2016;54(2):122-128 (In Russ.)]. doi: 10.14412/1995-44842016-122-128

4. Новикова ДС, Попкова ТВ, Насонов ЕЛ. Артериальная гипертензия при ревматоидном артрите. Научно-практическая ревматология. 2011;49(3):5268. [Novikova DS, Popkova TV, Nasonov EL. Arterial hypertension in rheumatoid arthritis. NauchcnoPrakticheskaya Revmatologia $=$ Rheumatology Science and Practice. 2011;49(3):52-68 (In Russ.)]. doi: 10.14412/1995-4484-2011-574

5. Бестаев ДВ, Каратеев ДЕ, Насонов ЕЛ. Поражение легких при ревматоидном артрите. Научнопрактическая ревматология. 2014;52(4):451-457. [Bestaev DV, Karateev DE, Nasonov EL. Pulmonary involvement in rheumatoid arthritis. NauchcnoPrakticheskaya Revmatologia $=$ Rheumatology Science and Practice. 2014;52(4):451-457 (In Russ.)]. doi: 10.14412/1995-4484-2014-451-457

6. Кондратьева ЛВ, Попкова ТВ, Насонов ЕЛ. Метаболический синдром при ревматоидном артрите. Научно-практическая ревматология. 2013;51(3):302312. [Kondratyeva LV, Popkova TV, Nasonov EL. Metabolic syndrome in rheumatoid arthritis. NauchcnoPrakticheskaya Revmatologia = Rheumatology Science and Practice. 2013;51(3):302-312 (In Russ.)]. doi: 10.14412/1995-4484-2013-1506

7. Насонов ЕЛ, Александрова ЕН, Новиков АА. Аутоиммунные ревматические заболевания: итоги и перспективы научных исследований. Научнопрактическая ревматология. 2015;53(3):230-237. [Nasonov EL, Aleksandrova EN, Novikov AA. Autoimmune rheumatic diseases: Results and prospects for researches. Nauchcno-Prakticheskaya Revmatologia $=$ Rheumatology Science and Practice. 2015;53(3):230-237 (In Russ.)]. doi: 10.14412/1995-4484-2015-230-237

8. Бекетова ТВ. Развитие ревматологии на этапе становления нового технологического уклада. Научнопрактическая ревматология. 2019;57(5):490-495. [Beketova TV. The development of rheumatology at the stage of formation of a new technological paradigm. Nauchcno-Prakticheskaya Revmatologia = Rheumatology Science and Practice. 2019;57(5):490-495 (In Russ.)]. doi: 10.14412/1995-4484-2019-490-495

9. Александрова ЕН, Насонов ЕЛ. Инновационные технологии в лабораторной диагностике ревматических заболеваний. Научно-практическая ревматология. 2010;48(2):13-20. [Aleksandrova EN, Nasonov EL. Innovative technologies in the laboratory diagnosis of rheumatic diseases. Nauchcno-Prakticheskaya Revmatologia $=$ Rheumatology Science and Practice. 2010;48(2):13-20 (In Russ.)]. doi: 10.14412/1995-44842010-1411

10. Александрова ЕН, Новиков АА, Насонов ЕЛ. Современные подходы к лабораторной диагностике ревматических заболеваний: роль молекулярных и клеточных биомаркеров. Научно-практическая ревматология. 2016;54(3):324-338. [Aleksandrova EN, Novikov AA, Nasonov EL. Current approaches to the laboratory diagnosis of rheumatic diseases: Role of molecular and cellular biomarkers. Nauchcno-Prakticheskaya Revmatologia $=$ Rheumatology Science and Practice .
2016;54(3):324-338 (In Russ.)]. doi: 10.14412/1995-44842016-324-338

11. Насонов ЕЛ. Фармакотерапия ревматоидного артрита: новая стратегия, новые мишени. Научнопрактическая ревматология. 2017;55(4):409-419. [Nasonov EL. Pharmacotherapy for rheumatoid arthritis: New strategy, new targets. Nauchcno-Prakticheskaya Revmatologia $=$ Rheumatology Science and Practice. 2017;55(4):409-419 (In Russ.)]. doi: 10.14412/1995-44842017-409-419

12. Насонов ЕЛ. Новые возможности фармакотерапии иммуновоспалительных ревматических заболеваний: фокус на ингибиторы интерлейкина 17. Научнопрактическая ревматология. 2017;55(1):68-86.

[Nasonov EL. New possibilities of pharmacotherapy for immunoinflammatory rheumatic diseases: A focus on inhibitors of interleukin-17. Nauchcno-Prakticheskaya Revmatologia $=$ Rheumatology Science and Practice. 2017;55(1):68-86 (In Russ.)]. doi: 10.14412/1995-44842017-68-86

13. Насонов ЕЛ, Денисов ЛН, Станислав МЛ. Интерлейкин 17 - новая мишень для антицитокиновой терапии иммуновоспалительных ревматических заболеваний. Научно-практическая ревматология. 2013;51(5):545-552. [Nasonov EL, Denisov LN, Stanislav ML. Interleukin-17 is a new target for anti-cytokine therapy of immune inflammatory rheumatic diseases. Nauchcno-Prakticheskaya Revmatologia = Rheumatology Science and Practice. 2013;51(5):545-552 (In Russ.)]. doi: 10.14412/1995-4484-2013-1547

14. Насонов ЕЛ, Александрова ЕН, Авдеева АС, Панасюк ЕЮ. Ингибиция интерлейкина 6 - новые возможности фармакотерапии иммуновоспалительных ревматических заболеваний. Научнопрактическая ревматология. 2013;51(4):416-427. [Nasonov EL, Aleksandrova EN, Avdeeva AS, Panasyuk EYu. Interleukin 6 inhibition: New possibilities of pharmacotherapy for immunoinflammatory rheumatic diseases. Nauchcno-Prakticheskaya Revmatologia $=$ Rheumatology Science and Practice. 2013;51(4):416-427 (In Russ.)]. doi: 10.14412/1995-4484-2013-1254

15. Насонов ЕЛ, Лила АМ. Ингибиция интерлейкина 6 при иммуновоспалительных ревматических заболеваниях: достижения, перспективы и надежды. Научнопрактическая ревматология. 2017;55(6):590-599. [Nasonov EL, Lila AM. Inhibition of interleukin 6 in immune inflammatory rheumatic diseases: Achievements, prospects, and hopes. NauchcnoPrakticheskaya Revmatologia $=$ Rheumatology Science and Practice. 2017;55(6):590-599 (In Russ.)]. doi: 10.14412/1995-4484-2017-590-599

16. Насонов ЕЛ, Лила АМ. Эффективность и безопасность сарилумаба (полностью человеческие моноклональные антитела к рецептору интерлейкина 6) при ревматоидном артрите: новые данные. Научнопрактическая ревматология. 2019;57(5):564-577. [Nasonov EL, Lila AM. The efficacy and safety of sarilumab, fully human monoclonal antibodies against interleukin 6 receptor, in rheumatoid arthritis: New evidence. Nauchcno-Prakticheskaya Revmatologia = Rheumatology Science and Practice. 2019;57(5):564-577 (In Russ.)]. doi: 10.14412/1995-4484-2019-564-57

17. Бекетова ТВ, Насонов ЕЛ. Инновационные методы лечения артериита Такаясу: в фокусе ингибиторы интерлейкина 6. Собственный опыт применения тоцилизумаба и обзор литературы. Научнопрактическая ревматология. 2017;55(5):536-548. [Beketova TV, Nasonov EL. Innovative treatments for Takayasu's arteritis: a focus on interleukin-6 inhibitors. The authors' experience with tocilizumab and a review 
of literature. Nauchcno-Prakticheskaya Revmatologia $=$ Rheumatology Science and Practice. 2017;55(5):536-548 (In Russ.)]. doi: 10.14412/1995-4484-2017-536-548

18. Ананьева ЛП. Перспективы применения тоцилизумаба при системной склеродермии. Научнопрактическая ревматология. 2015;53(6):632-640. [Ananyeva LP. Prospects for using tocilizumab in systemic sclerosis. Nauchcno-Prakticheskaya Revmatologia $=$ Rheumatology Science and Practice. 2015;53(6):632-640 (In Russ.)]. doi: 10.14412/1995-4484-2015-632-640

19. Насонов ЕЛ. Иммунопатология и иммунофармакотерапия коронавирусной болезни 2019 (COVID-19): фокус на интерлейкин 6. Научно-практическая ревматология. 2020;58(3):245-261. [Nasonov EL.

Immunopathology and immunopharmacotherapy of coronavirus disease 2019 (COVID-19): Focus on interleukin 6. Nauchcno-Prakticheskaya Revmatologia = Rheumatology Science and Practice. 2020;58(3):245-261 (In Russ.)]. doi: 10.14412/1995-4484-2020-245-261

20. Лисицына ТА, Вельтищев ДЮ, Лила АМ, Насонов ЕЛ. Интерлейкин 6 как патогенетический фактор, опосредующий формирование клинических проявлений, и мишень для терапии ревматических заболеваний и депрессивных расстройств. Научнопрактическая ревматология. 2019;57(3):318-327. [Lisitsyna TA, Veltishchev DYu, Lila AM, Nasonov EL. Interleukin 6 as a pathogenic factor mediating clinical manifestations and a therapeutic target for rheumatic diseases and depressive disorders. Nauchcno-Prakticheskaya Revmatologia $=$ Rheumatology Science and Practice. 2019;57(3):318-327 (In Russ.)]. doi: 10.14412/1995-44842019-318-327

21. Попкова ТВ, Новиков ДС, Насонов ЕЛ. Интерлейкин 6 и сердечно-сосудистая патология при ревматоидном артрите. Научно-практическая ревматология. 2011;49(4):64-72. [Popkova TV, Novikov DS, Nasonov EL. Interleykin 6 and cardiovascular pathology in rheumatoid arthritis. Nauchcno-Prakticheskaya Revmatologia $=$ Rheumatology Science and Practice. 2011;49(4):64-72 (In Russ.)]. doi: 10.14412/1995-44842011-63

22. Насонов ЕЛ. Роль интерлейкина 1 в развитии заболеваний человека. Научно-практическая ревматология. 2018;56:19-27. [Nasonov EL. The role of interleukin 1 in the development of human diseases. NauchcnoPrakticheskaya Revmatologia = Rheumatology Science and Practice. 2018;56:19-27 (In Russ.)]. doi: 10.14412/19954484-2018-19-27

23. Насонов ЕЛ, Файст Е. Болезнь Стилла взрослых: новые горизонты. Научно-практическая ревматология. 2021;59(6):645-665. [Nasonov EL, Feist E. Adult Still's disease: New horizons. Nauchcno-Prakticheskaya Revmatologia $=$ Rheumatology Science and Practice. 2021;59(6):645-665 (In Russ.)]. doi: 10.47360/1995-44842021-643-663

24. Насонов ЕЛ, Попкова ТВ. Роль интерлейкина 1 в развитии атеросклероза. Научно-практическая ревматология. 2018;56:28-34. [Nasonov EL, Popkova TV. Role of interleukin 1 in the development of atherosclerosis. Nauchcno-Prakticheskaya Revmatologia = Rheumatology Science and Practice. 2018;56:28-34 (In Russ.)]. doi: 10.14412/1995-4484-2018-28-34

25. Насонов ЕЛ. Применение канакинумаба при болезни Стилла взрослых. Научно-практическая ревматология. 2018;56:35-40. [Nasonov EL. Therapy with canakinumab for adult-onset Still's disease. Nauchcno-Prakticheskaya Revmatologia = Rheumatology Science and Practice. 2018;56:3540 (In Russ.)]. doi: 10.14412/1995-4484-2018-35-40

26. Елисеев МС, Насонов ЕЛ. Применение канакинумаба при подагре. Научно-практическая ревматология.
2018;56:41-48. [Eliseev MS, Nasonov EL. Therapy with canakinumab for gout. Nauchcno-Prakticheskaya Revmatologia $=$ Rheumatology Science and Practice. 2018;56:41-48 (In Russ.)]. doi: 10.14412/1995-4484-201841-48

27. Насонов ЕЛ, Амирджанова ВН. Новые аспекты фармакотерапии ревматоидного артрита: фокус на цертолизумаба пэгол. Научно-практическая ревматология. 2011;49(1):40-49. [Nasonov EL, Amirdzhanova VN. New aspects of the pharmacotherapy of rheumatoid arthritis: A focus on certolizumab pegol. Nauchcno-Prakticheskaya Revmatologia $=$ Rheumatology Science and Practice. 2011;49(1):40-49 (In Russ.)]. doi: 10.14412/1995-44842011-866

28. Каратеев ДЕ. Этанерцепт (обзор международных исследований). Научно-практическая ревматология. 2009;47(5):52-57. [Karateev DE. Etanercept (review of international studies). Nauchcno-Prakticheskaya Revmatologia $=$ Rheumatology Science and Practice. 2009;47(5):52-57 (In Russ.)]. doi: 10.14412/1995-44842009-589

29. Насонов ЕЛ. Применение ингибиторов фактора некроза опухоли при ревматоидном артрите: место этанерцепта. Научно-практическая ревматология. 2008;46(5s):1-20. [Nasonov EL. The use of tumor necrosis factor inhibitors in rheumatoid arthritis: The place of etanercept. Nauchcno-Prakticheskaya Revmatologia $=$ Rheumatology Science and Practice. 2008;46(5s):1-20 (In Russ.)]. doi: 10.14412/1995-4484-2008-701

30. Насонов ЕЛ, Коротаева ТВ. Перспективы применения моноклональных антител к интерлейкину 23 гуселькумаба при псориатическом артрите: новые данные. Научно-практическая ревматология. 2022. Принята к печати. [Nasonov EL, Korotaeva TV. Prospects for the use of monoclonal antibodies to interleukin 23, guselcumab in psoriatic arthritis: New data. Nauchcno-Prakticheskaya Revmatologia = Rheumatology Science and Practice. 2022. Accepted for publication (In Russ.)].

31. Бекетова ТВ, Арсеньев ЕВ. Интерлейкин 5 - новая мишень для терапии эозинофильного гранулематоза с полиангиитом. Научно-практическая ревматология. 2020;58(3):321-329. [Beketova TV, Arseniev EV. Interleukin-5 is a new target in the treatment of eosinophilic granulomatosis with polyangiitis. NauchcnoPrakticheskaya Revmatologia = Rheumatology Science and Practice. 2020;58(3):321-329 (In Russ.)]. doi: 10.14412/1995-4484-2020-321-329

32. Каратеев АЕ, Лила АМ, Алексеева ЛИ. Перспективы применения танезумаба при хронической боли. Научно-практическая ревматология. 2021;59(2):192200. [Karateev AE, Lila AM, Alekseeva LI. Use of tanezumab for chronic pain treatment. NauchcnoPrakticheskaya Revmatologia $=$ Rheumatology Science and Practice. 2021;59(2):192-200 (In Russ.)]. doi: 10.47360/1995-4484-2021-192-200

33. Насонов ЕЛ. Ритуксимаб в лечении ревматических болезней. Научно-практическая ревматология. 2008;46(1s):3-10. [Nasonov EL. Rituximab in the treatment of rheumatic diseases. Nauchcno-Prakticheskaya Revmatologia $=$ Rheumatology Science and Practice. 2008;46(1s):3-10 (In Russ.)]. doi: 10.14412/1995-44842008-1

34. Насонов ЕЛ. Перспективы анти-В-клеточной терапии в ревматологии. Научно-практическая ревматология. 2018;56(5):539-548. [Nasonov EL. Prospects for anti-Bcell therapy in rheumatology. Nauchcno-Prakticheskaya Revmatologia $=$ Rheumatology Science and Practice. 2018;56(5):539-548 (In Russ.)]. doi: 10.14412/1995-44842018-539-548 
35. Насонов ЕЛ, Бекетова ТВ, Ананьева ЛП, Васильев ВИ, Соловьев СК, Авдеева АС. Перспективы анти-В-клеточной терапии при иммуновоспалительных ревматических заболеваниях. Научнопрактическая ревматология. 2019;57:1-40.

[Nasonov EL, Beketova TV, Ananyeva LP, Vasilyev VI, Solovyev SK, Avdeeva AS. Prospects for anti-B-cell therapy in immuno-inflammatory rheumatic diseases. Nauchcno-Prakticheskaya Revmatologia = Rheumatology Science and Practice. 2019;57:1-40 (In Russ.)]. doi: 10.14412/1995-4484-2019-3-40

36. Левицки А, Линдер С, ван Волленховен РФ. Ритуксимаб в терапии системной красной волчанки. Научно-практическая ревматология. 2013;51(3):223239. [Levitsky A, Linder S, van Vollenhoven RF. Rituximab in the management of systemic lupus erythematosus. Nauchcno-Prakticheskaya Revmatologia = Rheumatology Science and Practice. 2013;51(3):223-239 (In Russ.)]. doi: 10.14412/1995-4484-2013-1494

37. Ананьева ЛП, Соловьев СК, Бекетова ТВ, Васильев ВИ, Антелава ОА, Александрова ЕН, и др. Анти-В-клеточная терапия при иммуновоспалительных ревматических заболеваниях: эффективность и переносимость у 229 больных. Научно-практическая ревматология. 2014;52(5):495-506. [Ananieva LP, Soloviyov SK, Beketova TV, Vasiliev VI, Antelava OA, Aleksandrova EN, et al. Anti-B-cell therapy at immune inflammatory rheumatic diseases: Efficacy and tolerability in 229 patients. Nauchcno-Prakticheskaya Revmatologia = Rheumatology Science and Practice. 2014;52(5):495-506 (In Russ.)]. doi: 10.14412/1995-4484-2014-495-506

38. Арефьева АН. Применение ритуксимаба при системной красной волчанке у детей: обзор литературы. Научно-практическая ревматология. 2019;57(5):578583. [Arefyeva AN. Use of rituximab in systemic lupus erythematosus in children: A review. Nauchcno-

Prakticheskaya Revmatologia = Rheumatology Science and Practice. 2019;57(5):578-583 (In Russ.)]. doi: 10.14412/1995-4484-2019-578-583

39. Кусевич ДА, Авдеева АС. Эффективность и безопасность применения ритуксимаба при ревматоидном артрите (новые данные). Научно-практическая ревматология. 2017;55(4):420-428. [Kusevich DA, Avdeeva AS. The efficacy and safety of rituximab in rheumatoid arthritis: New evidence. Nauchcno-Prakticheskaya Revmatologia $=$ Rheumatology Science and Practice. 2017;55(4):420-428 (In Russ.)]. doi: 10.14412/1995-44842017-420-428

40. Насонов ЕЛ, Авдеева АС. Деплеция В-клеток при иммуновоспалительных ревматических заболеваниях и коронавирусная болезнь 2019 (COVID-19). Научно-практическая ревматология. 2021;59(4):384393. [Nasonov EL, Avdeeva AS. B cell depletion in immune-mediated rheumatic diseases and coronavirus disease 2019 (COVID-19). Nauchcno-Prakticheskaya Revmatologia $=$ Rheumatology Science and Practice. 2021;59(4):384-393 (In Russ.)]. doi: 10.47360/1995-44842021-384-393

41. Насонов ЕЛ. Абатацепт при ревматоидном артрите: новая форма, новые механизмы, новые возможности. Научно-практическая ревматология. 2015;53(5):522541. [Nasonov EL. Abatacept for rheumatoid arthritis: A novel formulation, new mechanisms, new possibilities. Nauchcno-Prakticheskaya Revmatologia = Rheumatology Science and Practice. 2015;53(5):522-541 (In Russ.)]. doi: 10.14412/1995-4484-2015-522-541

42. Борисова МА, Лукина ГВ, Сигидин ЯА, Лучихина ЕЛ, Каратеев ДЕ, Аронова ЕС, и др. Сравнительная оценка эффективности и безопасности абатацепта у пациентов с разной длительностью ревматоидного артри- та. Научно-практическая ревматология. 2016;54(6):667673. [Borisova MA, Lukina GV, Sigidin YaA,

Luchikhina EL, Karateev DE, Aronova ES, et al. Comparative evaluation of the efficacy and safety of abatacept in patients with different duration of rheumatoid arthritis. Nauchcno-Prakticheskaya Revmatologia $=$ Rheumatology Science and Practice. 2016;54(6):667-673 (In Russ.)]. doi: 10.14412/1995-4484-2016-667-673

43. Борисова МА, Лукина ГВ, Сигидин ЯА, Лучихина ЕЛ, Каратеев ДЕ, Новиков АА, и др. Влияние абатацепта на динамику биомаркеров крови у больных ревматоидным артритом. Научно-практическая ревматология. 2017;55(4):368-375. [Borisova MA, Lukina GV, Sigidin YaA, Luchikhina EL, Karateev DE, Novikov AA, et al. The effect of abatacept on blood biomarkers in patients with rheumatoid arthritis. NauchcnoPrakticheskaya Revmatologia = Rheumatology Science and Practice. 2017;55(4):368-375 (In Russ.)]. doi: 10.14412/1995-4484-2017-368-375

44. Насонов ЕЛ, Решетняк ТМ, Денисов ЛН, Станислав МЛ, Соловьев СК. Белимумаб: прогресс в лечении системной красной волчанки. Научнопрактическая ревматология. 2012;50(5):13-19.

[Nasonov EL, Reshetnyak TM, Denisov LN, Stanislav ML, Solovyov SK. Belimumab: Advances in drug therapy for systemic lupus erythematosus. NauchcnoPrakticheskaya Revmatologia = Rheumatology Science and Practice. 2012;50(5):13-19 (In Russ.)]. doi: 10.14412/1995-4484-2012-1174

45. Насонов ЕЛ, Попкова ТВ, Лила АМ. Белимумаб в лечении системной красной волчанки: 20 лет фундаментальных исследований, 10 лет клинической практики. Научно-практическая ревматология. 2021;59(4):367-383. [Nasonov EL, Popkova TV, Lila AM. Belimumab in the treatment of systemic lupus erythematosus: 20 years of basic research, 10 years of clinical practice. Nauchcno-Prakticheskaya Revmatologia = Rheumatology Science and Practice. 2021;59(4):367-383 (In Russ.)]. doi: 10.47360/1995-4484-2021-367-383

46. Супоницкая ЕВ, Александрова ЕН, Алексанкин АП, Насонов ЕЛ. Влияние терапии генно-инженерными биологическими препаратами на субпопуляции В-лимфоцитов при ревматических заболеваниях: новые данные. Научно-практическая ревматология. 2015;53(1):78-83. [Suponitskaya EV, Aleksandrova EN, Aleksankin AP, Nasonov EL. Impact of therapy with biological agents on B-lymphocyte subpopulations in rheumatic diseases: New evidence. Nauchcno-Prakticheskaya Revmatologia $=$ Rheumatology Science and Practice. 2015;53(1):78-83 (In Russ.)]. doi: 10.14412/1995-44842015-78-83

47. Насонов ЕЛ, Соловьев СК. Перспективы фармакотерапии системной красной волчанки. Научнопрактическая ревматология. 2014;52(3):311-321. [Nasonov EL, Solovyev SK. Prospects for pharmacotherapy of systemic lupus erythematosus. NauchcnoPrakticheskaya Revmatologia $=$ Rheumatology Science and Practice. 2014;52(3):311-321 (In Russ.)]. doi: 10.14412/1995-4484-2014-311-321

48. Насонов ЕЛ, Авдеева АС. Иммуновоспалительные ревматические заболевания, связанные с интерфероном типа I: новые данные. Научно-практическая ревматология. 2019;57(4):452-461. [Nasonov EL, Avdeeva AS. Immunoinflammatory rheumatic diseases associated with type I interferon: New evidence. Nauchcno-Prakticheskaya Revmatologia = Rheumatology Science and Practice. 2019;57(4):452-461 (In Russ.)]. doi: 10.14412/1995-4484-2019-452-461

49. Насонов ЕЛ, Авдеева АС, Попкова ТВ. Новые возможности фармакотерапии системной красной вол- 
чанки: перспективы применения анифролумаба (моноклональные антитела к рецепторам интерферона типа I). Научно-практическая ревматология. 2021;59(5):537-546. [Nasonov EL, Avdeeva AS, Popkova TV. New possibilities of pharmacotherapy for systemic lupus erythematosus: Prospects for the use of anifrolumab (monoclonal antibodies to type I interferon receptor). Nauchcno-Prakticheskaya Revmatologia $=$ Rheumatology Science and Practice. 2021;59(5):537-546 (In Russ.)]. doi: 10.47360/1995-4484-2021-537-546

50. Насонов ЕЛ, Лила АМ. Ингибиторы Янус-киназ при иммуновоспалительных ревматических заболеваниях: новые возможности и перспективы. Научнопрактическая ревматология. 2019;57(1):8-16. [Nasonov EL, Lila AM. Janus kinase inhibitors in immuno-inflammatory rheumatic diseases: New opportunities and prospects. Nauchcno-Prakticheskaya Revmatologia $=$ Rheumatology Science and Practice. 2019;57(1):8-16 (In Russ.)]. doi: 10.14412/1995-4484-2019-8-16

51. Насонов ЕЛ. Новые подходы к фармакотерапии ревматоидного артрита: тофацитиниб. Научнопрактическая ревматология. 2014;52(2):209-221. [Nasonov EL. New approaches to pharmacotherapy of rheumatoid arthritis: Tofacitinib. Nauchcno-Prakticheskaya Revmatologia $=$ Rheumatology Science and Practice. 2014;52(2):209-221 (In Russ.)]. doi: 10.14412/1995-44842014-209-221

52. Насонов ЕЛ, Авдеева АС, Лила АМ. Эффективность и безопасность тофацитиниба при иммуновоспалительных ревматических заболеваниях (часть I). Научно-практическая ревматология. 2020;58(1):62-79. [Nasonov EL, Avdeeva AS, Lila AM. Efficacy and safety of tofacitinib for immune-mediated inflammatory rheumatic diseases (Part I). Nauchcno-Prakticheskaya Revmatologia $=$ Rheumatology Science and Practice. 2020;58(1):62-79 (In Russ.)]. doi: 10.14412/1995-44842020-62-79

53. Насонов ЕЛ, Авдеева АС, Лила АМ. Эффективность и безопасность тофацитиниба при иммуновоспалительных ревматических заболеваниях (часть II). Научно-практическая ревматология. 2020;58(2):214224. [Nasonov EL, Avdeeva AS, Lila AM. Efficacy and safety of tofacitinib for immunemediated inflammatory rheumatic diseases (Part II). Nauchcno-Prakticheskaya Revmatologia $=$ Rheumatology Science and Practice. 2020;58(2):214-224 (In Russ.)]. doi: 10.14412/1995-44842020-214-224

54. Насонов ЕЛ, Лила АМ. Барицитиниб: новые возможности фармакотерапии ревматоидного артрита и других иммуновоспалительных ревматических заболеваний. Научно-практическая ревматология. 2020;58(3):304-316. [Nasonov EL, Lila AM. Baricitinib: New pharmacotherapy options for rheumatoid arthritis and other immune-mediated inflammatory rheumatic diseases. Nauchcno-Prakticheskaya Revmatologia $=$ Rheumatology Science and Practice. 2020;58(3):304-316 (In Russ.)]. doi: 10.14412/1995-4484-2020-304-316

55. Насонов ЕЛ, Лила АМ. Перспективы применения упадацитиниба при ревматоидном артрите и других иммуновоспалительных ревматических заболеваниях. Научно-практическая ревматология. 2020;58(5):532543. [Nasonov EL, Lila AM. The progress of rheumatology in the 21 st century potential uses of upadacitinib in rheumatoid arthritis and other inflammatory rheumatic diseases. Nauchcno-Prakticheskaya Revmatologia $=$ Rheumatology Science and Practice. 2020;58(5):532-543 (In Russ.)]. doi: 10.47360/1995-4484-2020-532-543

56. Насонов ЕЛ, Мазуров ВИ, Каратеев ДЕ, Лукина ГВ, Жиляев ЕВ, Амирджанова ВН, и др. Проект рекомендаций по лечению ревматоидного артрита
Общероссийской общественной организации «Ассоциация ревматологов России» - 2014 (часть 1). Научно-практическая ревматология. 2014;52(5):477494. [Nasonov EL, Mazurov VI, Karateev DE, Lukina GV, Zhilyaev EV, Amirdzhanova VN, et al. Project: Recommendations on treatment of rheumatoid arthritis developed by All-Russian public organization «Association of rheumatologists of Russia» - 2014 (Part 1). Nauchcno-Prakticheskaya Revmatologia $=$ Rheumatology Science and Practice. 2014;52(5):477-494 (In Russ.)]. doi: 10.14412/1995-4484-2014-477-494

57. Насонов ЕЛ, Каратеев ДЕ, Чичасова НВ. Рекомендации EULAR по лечению ревматоидного артрита - 2013: общая характеристика и дискуссионные проблемы. Научно-практическая ревматология. 2013;51(6):609-622. [Nasonov EL, Karateev DE, Chichasova NV. EULAR recommendations for the treatment of rheumatoid arthritis - 2013: General characteristics and disputable problems. Nauchcno-Prakticheskaya Revmatologia $=$ Rheumatology Science and Practice. 2013;51(6):609-622 (In Russ.)]. doi: 10.14412/1995-44842013-609-22

58. Насонов ЕЛ. Фармакотерапия ревматоидного артрита: российские и международные рекомендации. Научно-практическая ревматология. 2016;54(5):557571. [Nasonov EL. Pharmacotherapy for rheumatoid arthritis: Russian and international guidelines. NauchcnoPrakticheskaya Revmatologia = Rheumatology Science and Practice. 2016;54(5):557-571 (In Russ.)]. doi: 10.14412/1995-4484-2016-557-571

59. Насонов ЕЛ, Каратеев ДЕ, Чичасова НВ. Новые рекомендации по лечению ревматоидного артрита (EULAR, 2013): место метотрексата. Научно-практическая ревматология. 2014;52(1):8-26. [Nasonov EL, Karateev DE, Chichasova NV. New recommendations for the management of rheumatoid arthritis (EULAR, 2013): The role of methotrexate. Nauchcno-Prakticheskaya Revmatologia $=$ Rheumatology Science and Practice. 2014;52(1):8-26 (In Russ.)]. doi: 10.14412/1995-44842014-8-26

60. Насонов ЕЛ. Новые рекомендации по лечению ревматоидного артрита (EULAR, 2013): место глюкокортикоидов. Научно-практическая ревматология. 2015;53(3):238-250. [Nasonov EL. New guidelines for the management of rheumatoid arthritis (EULAR, 2013): The place of glucocorticoids. Nauchcno-Prakticheskaya Revmatologia $=$ Rheumatology Science and Practice. 2015;53(3):238-250 (In Russ.)]. doi: 10.14412/1995-44842015-238-250

61. Насонов ЕЛ. Рекомендации EULAR по диагностике и лечению раннего артрита: 2016. Научно-практическая ревматология. 2017;55(2):138-150. [Nasonov EL. The 2016 EULAR guidelines for the diagnosis and treatment of early arthritis. Nauchcno-Prakticheskaya Revmatologia $=$ Rheumatology Science and Practice. 2017;55(2):138-150 (In Russ.)]. doi: 10.14412/1995-4484-2017-138-150

62. Орлова ЕА, Каратеев ДЕ, Булгакова НА. Лечение ревматоидного артрита до достижения цели (Treat to Target): российская версия международных рекомендаций для пациентов. Научно-практическая ревматология. 2013;51(3):246-254. [Orlova EV, Karateev DE, Bulgakova NA. Treating rheumatoid arthritis to target: Russian version of international guidelines for patients. Nauchcno-Prakticheskaya Revmatologia $=$ Rheumatology Science and Practice. 2013;51(3):246-254 (In Russ.)]. doi: 10.14412/1995-4484-2013-1496

63. Дубинина ТВ, Гайдукова ИЗ, Годзенко АА, Лапшина СА, Ребров АП, Румянцева ОА, и др. Рекомендации по оценке активности болезни и функционального состояния больных анкилозирующим 
спондилитом в клинической практике. Научнопрактическая ревматология. 2017;55(4):344-350. [Dubinina TV, Gaidukova IZ, Godzenko AA, Lapshina SA, Rebrov AP, Rumyansteva OA, et al. Guidelines for the assessment of disease activity and functional status in patients with ankylosing spondylitis in clinical practice. Nauchcno-Prakticheskaya Revmatologia $=$ Rheumatology Science and Practice. 2017;55(4):344-350 (In Russ.)]. doi: 10.14412/1995-4484-2017-344-350

64. Гайдукова ИЗ, Ребров АП, Коротаева ТВ, Дубинина ТВ, Оттева ЭН, Бадокин ВВ, и др. Ремиссия при аксиальных спондилоартритах - определение и инструменты оценки (рекомендации Экспертной группы по изучению спондилоартритов при Общероссийской общественной организации «Ассоциация ревматологов России»). Научнопрактическая ревматология. 2018;56(1):10-14.

[Gaidukova IZ, Rebrov AP, Korotaeva TV, Dubinina TV, Otteva EN, Badokin VV, et al. Remission in axial spondyloarthritis: Definition and evaluation tools (recommendations of the Spondyloarthritis Study Group of Experts, AllRussian public organization «Association of rheumatology of Russia»). Nauchcno-Prakticheskaya Revmatologia $=$ Rheumatology Science and Practice. 2018;56(1):10-14 (In Russ.)]. doi: 10.14412/1995-4484-2018-10-14

65. Эрдес ШФ. Новая редакция Т2Т (лечение до достижения цели) при спондилоартритах. Научнопрактическая ревматология. 2017;55(5):572-575. [Erdes SF. The new version of T2T (Treat-to-Target) for spondyloarthritides. Nauchcno-Prakticheskaya Revmatologia $=$ Rheumatology Science and Practice. 2017;55(5):572-575 (In Russ.)]. doi: 10.14412/1995-44842017-572-575

66. Дубинина ТВ, Подряднова МВ, Красненко СО, Эрдес ШФ. Лечебная физкультура при анкилозирующем спондилите: рекомендации и реальность. Научно-практическая ревматология. 2014;52(2):187191. [Dubinina TV, Podryadnova MV, Krasnenko SO, Erdes SF. Therapeutic exercise for patients with ankylosing spondylitis: Recommendations and reality. NauchcnoPrakticheskaya Revmatologia $=$ Rheumatology Science and Practice. 2014;52(2):187-191 (In Russ.)]. doi: 10.14412/1995-4484-2014-187-191

67. Гайдукова ИЗ, Ребров АП, Оттева ЭН, Бадокин ВВ, Бочкова АГ, Бугрова ОВ, и др. Применение нестероидных противовоспалительных препаратов для лечения аксиальных спондилоартритов, включая анкилозирующий спондилит, мониторинг эффективности и безопасности (проект рекомендаций группы экспертов по диагностике и лечению спондилоартритов). Научно-практическая ревматология. 2016;54(1S):67-74. [Gaidukova IZ, Rebrov AP, Otteva EN, Badokin VV, Bochkova AG, Bugrova OV, et al. Use of nonsteroidal anti-inflammatory drugs for the treatment of axial spondyloarthritis, including ankylosing spondylitis, monitoring their efficacy and safety (draft guidelines of the Expert Spondyloarthritis Diagnosis and Treatment Group). Nauchcno-Prakticheskaya Revmatologia = Rheumatology Science and Practice. 2016;54(1S):67-74 (In Russ.)]. doi: 10.14412/1995-4484-2016-1S-67-74

68. Эрдес ШФ, Бочкова АГ, Dubinina TV, Лапшина CA, Мясоутова ЛИ, Румянцева ОА, и др. Проект рабочей классификации анкилозирующего спондилита. Научно-практическая ревматология. 2013;51(6):604608. [Erdes SF, Bochkova AG, Dubinina TV,

Lapshina SA, Myasoutova LI, Rumyantseva OA, et al. Project of working classification of ankylosing spondilytis. Nauchcno-Prakticheskaya Revmatologia = Rheumatology Science and Practice. 2013;51(6):604-608 (In Russ.)]. doi: 10.14412/1995-4484-2013-604-8
69. Елисеев МС. Новые международные рекомендации по диагностике и лечению подагры. Научнопрактическая ревматология. 2014;52(2):141-146. [Eliseev MS. New international recommendations for the diagnosis and treatment of gout. Nauchcno-Prakticheskaya Revmatologia = Rheumatology Science and Practice. 2014;52(2):141-146 (In Russ.)]. doi: 10.14412/1995-4484-2014-141-146

70. Елисеев MC. Обновленные рекомендации EULAR по лечению подагры. Комментарии к некоторым позициям. Научно-практическая ревматология. 2017;55(6):600-609. [Eliseev MS. Updated EULAR guidelines for the management of gout. Comments on certain items. Nauchcno-Prakticheskaya Revmatologia $=$ Rheumatology Science and Practice. 2017;55(6):600-609 (In Russ.)]. doi: 10.14412/1995-4484-2017-600-609

71. Елисеев МС. Классификационные критерии подагры (рекомендации ACR/EULAR). Научно-практическая ревматология. 2015;53(6):581-585. [Eliseev MS. Gout classification criteria (ACR/EULAR guidelines). Nauchcno-Prakticheskaya Revmatologia = Rheumatology Science and Practice. 2015;53(6):581-585 (In Russ.)]. doi: 10.14412/1995-4484-2015-581-585

72. Елисеев МС. Рекомендации Американской коллегии ревматологов (2020 г.) по ведению больных подагрой: что нового и что спорно. Научно-практическая ревматология. 2021;59(2):129-133. [Eliseev MS. ACR management guidelines for the treatment of gout: What's new and what's controversial. Nauchcno-Prakticheskaya Revmatologia $=$ Rheumatology Science and Practice. 2021;59(2):129-133 (In Russ.)]. doi: 10.47360/1995-44842021-129-133

73. Владимиров СА, Елисеев МС. Современная стратегия лечения болезни депонирования кристаллов пирофосфата кальция. Научно-практическая ревматология. 2018;56(6):746-752. [Vladimirov SA, Eliseev MS. Current strategy in the treatment of calcium pyrophosphate crystal deposition disease. Nauchcno-Prakticheskaya Revmatologia = Rheumatology Science and Practice. 2018;56(6):746-752 (In Russ.)]. doi: 10.14412/1995-4484-2018-746-752

74. Попкова ТВ, Панафидина ТА, Соловьев СК. По материалам обновленных рекомендаций Европейской антиревматической лиги (EULAR) по лечению системной красной волчанки - 2019: дискуссионные вопросы и комментарии. Научно-практическая ревматология. 2019;57(5):496-510. [Popkova TV, Panafidina TA, Solovyev SK. According to the 2019 updated European League Against Rheumatism (EULAR) recommendations for the treatment of systemic lupus erythematosus: Debatable issues and comments. NauchcnoPrakticheskaya Revmatologia $=$ Rheumatology Science and Practice. 2019;57(5):496-510 (In Russ.)]. doi: 10.14412/1995-4484-2019-496-510

75. Асеева ЕА, Соловьев СК, Насонов ЕЛ. Современные методы оценки активности системной красной волчанки. Научно-практическая ревматология. 2013;51(2):186-200. [Aseeva EA, Solovyev SK, Nasonov EL. Current methods for evaluating the activity of systemic lupus erythematosus. Nauchcno-Prakticheskaya Revmatologia $=$ Rheumatology Science and Practice. 2013;51(2):186-200 (In Russ.)]. doi: 10.14412/1995-44842013-648

76. Панафидина ТА, Попкова ТВ, Соловьев СК. Мониторинг больных системной красной волчанкой: общая характеристика и дискуссионные вопросы (по материалам рекомендаций Канадской ассоциации ревматологов). Научно-практическая ревматология. 2019;57(3):255-264. [Panafidina TA, Popkova TV, Solovyev SK. Monitoring patients with systemic lupus erythematosus: General characteristics and discussion ques- 
tions (according to the Canadian Rheumatology Association recommendations). Nauchcno-Prakticheskaya Revmatologia $=$ Rheumatology Science and Practice. 2019;57(3):255-264 (In Russ.)]. doi: 10.14412/1995-44842019-255-264

77. Каледа МИ, Никишина ИП. Современные международные рекомендации по диагностике и лечению системной красной волчанки с ювенильным дебютом. Научно-практическая ревматология. 2018;56(4):405415. [Kaleda MI, Nikishina IP. Current international guidelines for the diagnosis and treatment of juvenile-onset systemic lupus erythematosus. Nauchcno-Prakticheskaya Revmatologia $=$ Rheumatology Science and Practice. 2018;56(4):405-415 (In Russ.)]. doi: 10.14412/1995-44842018-405-415

78. Бекетова ТВ, Волков МЮ. Международные рекомендации по диагностике и лечению эозинофильного гранулематоза с полиангиитом - 2015. Научнопрактическая ревматология. 2016;54(2):129-137. [Beketova TV, Volkov MYu. The 2015 International guidelines for the diagnosis and treatment of eosinophilic granulomatosis with polyangiitis. Nauchcno-Prakticheskaya Revmatologia $=$ Rheumatology Science and Practice. 2016;54(2):129-137 (In Russ.)]. doi: 10.14412/1995-44842016-129-137

79. Бекетова ТВ, Сатыбалдыев АМ, Денисов ЛН. Международные рекомендации по ведению больных гигантоклеточным артериитом и ревматической полимиалгией: итоги 2015 года. Научно-практическая ревматология. 2016;54(4):390-394. [Beketova TV, Satybaldyev AM, Denisov LN. International guidelines for the management of giant cell arteritis and polymyalgia rheumatica: The 2015 results. Nauchcno-Prakticheskaya Revmatologia $=$ Rheumatology Science and Practice. 2016;54(4):390-394 (In Russ.)]. doi: 10.14412/1995-44842016-390-394

80. Бекетова TB. Европейские (EULAR/ERA-EDTA) рекомендации по диагностике и лечению АНЦАассоциированных системных васкулитов - 2016. Научно-практическая ревматология. 2017;55(1):12-16. [Beketova TV. The 2016 European (EULAR/ERA-EDTA) recommendations for the diagnosis and management of ANCA-associated systemic vasculitis. NauchcnoPrakticheskaya Revmatologia $=$ Rheumatology Science and Practice. 2017;55(1):12-16 (In Russ.)]. doi: 10.14412/1995-4484-2017-12-16

81. Бекетова ТВ, Попов ИЮ, Бабак ВВ. Обзор рекомендаций по лечению АНЦА-ассоциированных системных васкулитов, представленных в 2021 г. Американской коллегией ревматологов и Фондом васкулитов. Научно-практическая ревматология. 2021;59(6):684-692. [Beketova TV, Popov IYu, Babak VV. Review of guideline for the management of ANCAassociated vasculitis, presented in 2021 by the American College of Rheumatology/Vasculitis Foundation. Nauchcno-Prakticheskaya Revmatologia = Rheumatology Science and Practice. 2021;59(6):684-692 (In Russ.)]. doi: 10.47360/1995-4484-2021-684-692

82. Бекетова ТВ, Попов ИЮ, Зеленов ВА. Обзор рекомендаций American College of Rheumatology/Vasculitis Foundation по лечению системных васкулитов крупных сосудов (гигантоклеточного артериита и артериита Такаясу). Научно-практическая ревматология. 2022. Принята к печати. [Beketova TV, Popov IYu, Zelenov VA. Review of American College of Rheumatology/Vasculitis Foundation recommendations for the treatment of systemic large vessel vasculitis (giant cell arteritis and Takayasu's arteritis). NauchcnoPrakticheskaya Revmatologia $=$ Rheumatology Science and Practice. 2022. Accepted for publication (In Russ.)].
83. Белов БС, Кузьмина НН, Медынцева ЛГ, Бабаева АР, Шостак НА, Жиляев ЕВ, и др. Диагностика острой ревматической лихорадки. Научно-практическая ревматология. 2016;54(4):395-397. [Belov BS,

Kuzmina NN, Medyntseva LG, Babaeva AR, Shostak NA, Zhilyaev EV, et al. Diagnosis of acute rheumatic fever. Nauchcno-Prakticheskaya Revmatologia = Rheumatology Science and Practice. 2016;54(4):395-397 (In Russ.)]. doi: 10.14412/1995-4484-2016-395-397

84. Кузьмина НН, Белов БС, Медынцева ЛГ. Острая ревматическая лихорадка в XXI веке - проблема, которую забывать нельзя. Научно-практическая ревматология. 2016;54(1):5-9. [Kuzmina NN, Belov BS, Medyntseva LG. Acute rheumatic fever in the 21st century: The problem that cannot be forgotten. NauchcnoPrakticheskaya Revmatologia $=$ Rheumatology Science and Practice. 2016;54(1):5-9 (In Russ.)]. doi: 10.14412/1995-4484-2016-5-9

85. Белов БС, Ананьева ЛП. Болезнь Лайма: современные подходы к профилактике, диагностике и лечению (по материалам международных рекомендаций 2020 г.). Научно-практическая ревматология. 2021;59(5):547-554. [Belov BS, Ananyeva LP. Lyme disease: Modern approaches to prevention, diagnosis and treatment. Nauchcno-Prakticheskaya Revmatologia $=$ Rheumatology Science and Practice. 2021;59(5):547-554 (In Russ.)]. doi: 10.47360/1995-4484-2021-547-554

86. Лисицына ТА, Алекберова ЗС, Голоева РГ. Новые рекомендации по ведению пациентов с болезнью/ синдромом Бехчета (EULAR, 2018). Научнопрактическая ревматология. 2019;57(2):133-141. [Lisitsyna TA, Alekberova ZS, Goloeva RG. New guidelines for the management of patients with Behcet's disease/syndrome (EULAR, 2018). Nauchcno-Prakticheskaya Revmatologia $=$ Rheumatology Science and Practice. 2019;57(2):133-141 (In Russ.)]. doi: 10.14412/1995-44842019-133-141

87. Сокол ЕВ. Новые классификационные критерии IgG4-связанного заболевания Американской коллегии ревматологов (ACR)/Европейской антиревматической лиги (EULAR), 2019 г. Научно-практическая ревматология. 2020;58(4):368-375. [Sokol EV. The new 2019 American College of Rheumatology (ACR)/ European League Against Rheumatism (EULAR) classification criteria for IgG4-related disease. NauchcnoPrakticheskaya Revmatologia $=$ Rheumatology Science and Practice. 2020;58(4):368-375 (In Russ.)]. doi: 10.47360/1995-4484-2020-368-375

88. Торопцова НВ. Обзор клинических рекомендаций Американской коллегии ревматологов (ACR) по профилактике и лечению глюкокортикоидного остеопороза. Научно-практическая ревматология. 2018;56(2):144151. [Toroptsova NV. Review of American College of Rheumatology (ACR) clinical guidelines for the prevention and treatment of glucocorticoid-induced osteoporosis. Nauchcno-Prakticheskaya Revmatologia = Rheumatology Science and Practice. 2018;56(2):144-151 (In Russ.)]. doi: 10.14412/1995-4484-2018-144-151

89. Лесняк ОМ, Никитинская ОА, Торопцова НВ, Белая ЖЕ, Белова КЮ, Бордакова ЕВ, и др. Профилактика, диагностика и лечение дефицита витамина D и кальция у взрослого населения России и пациентов с остеопорозом (по материалам подготовленных клинических рекомендаций). Научнопрактическая ревматология. 2015;53(4):403-408. [Lesnyak OM, Nikitinskaya OA, Toroptsova NV, Belaya ZE, Belova KYu, Bordakova EV, et al. The prevention, diagnosis, and treatment of vitamin $\mathrm{D}$ and calcium deficiencies in the adult population of Russia and in patients with osteoporosis (according to the materi- 
als of prepared clinical recommendations). NauchcnoPrakticheskaya Revmatologia $=$ Rheumatology Science and Practice. 2015;53(4):403-408 (In Russ.)]. doi: 10.14412/1995-4484-2015-403-408

90. Сафонова ЮА, Зоткин ЕГ, Торопцова НВ. Диагностика риска и профилактика падений: проект клинических рекомендаций Ассоциации ревматологов России и Российской ассоциации по остеопорозу. Научно-практическая ревматология. 2020;58(2):133139. [Safonova YuA, Zotkin EG, Toroptsova NV. Diagnosis for risk for falls and their prevention: Draft clinical guidelines by the Association of Rheumatologists of Russia and the Russian Osteoporosis Association. Nauchcno-Prakticheskaya Revmatologia = Rheumatology Science and Practice. 2020;58(2):133-139 (In Russ.)]. doi: 10.14412/1995-4484-2020-133-139

91. Белов БС, Тарасова ГМ, Муравьева НВ. Вакцинация в ревматологии - 2019 (по материалам рекомендаций EULAR). Научно-практическая ревматология. 2019;57(6):618-625. [Belov BS, Tarasova GM, Muravyeva NV. Vaccination in rheumatology (the 2019 update of EULAR recommendations). NauchcnoPrakticheskaya Revmatologia $=$ Rheumatology Science and Practice. 2019;57(6):618-625 (In Russ.)]. doi: 10.14412/1995-4484-2019-618-625

92. Амирджанова ВН, Каратеев АЕ, Погожева ЕЮ. Обзор рекомендаций Американской коллегии ревматологов и Американской ассоциации хирургов по периоперационному ведению и антиревматической терапии пациентов с ревматическими заболеваниями перед тотальным эндопротезированием коленных и тазобедренных суставов - 2017. Научно-практическая ревматология. 2018;56(5):549-555. [Amirdzhanova VN, Karateev AE, Pogozheva EYu. Review of the 2017 American College of Rheumatology/American Association of Hip and Knee Surgeons guidelines for the perioperative management and antirheumatic therapy of patients with rheumatic diseases before total knee and hip arthroplasty. Nauchcno-Prakticheskaya Revmatologia = Rheumatology Science and Practice. 2018;56(5):549-555 (In Russ.)]. doi: 10.14412/1995-4484-2018-549-555

93. Насонов ЕЛ, Лила АМ, Мазуров ВИ, Белов БС, Каратеев АЕ, Дубинина ТВ, и др. Коронавирусная болезнь 2019 (COVID-19) и иммуновоспалительные ревматические заболевания. Рекомендации Общероссийской общественной организации «Ассоциация ревматологов России». Научнопрактическая ревматология. 2021;59(3):239-254. [Nasonov EL, Lila AM, Mazurov VI, Belov BS, Karateev AE, Dubinina TV, et al. Coronavirus disease 2019 (COVID-19) and immune-mediated rheumatic diseases. Recommendations of the Association of Rheumatologists of Russia. Nauchcno-Prakticheskaya Revmatologia $=$ Rheumatology Science and Practice. 2021;59(3):239-254 (In Russ.)]. doi: 10.47360/1995-44842021-239-254

94. Попкова ТВ, Новикова ДС. По материалам новых рекомендаций Европейской антиревматической лиги (EULAR) по снижению кардиоваскулярного риска у пациентов с воспалительными артритами 2015/2016: общая характеристика и дискуссионные проблемы. Научно-практическая ревматология. 2018;56(3):272-279. [Popkova TV, Novikova DS. According to the materials of the 2015/2016 new European League against Rheumatism (EULAR) guidelines for reducing cardiovascular risk in patients with inflammatory arthritis: General characterization and discussion problems. Nauchcno-Prakticheskaya Revmatologia $=$ Rheumatology Science and Practice. 2018;56(3):272-279 (In Russ.)]. doi: 10.14412/1995-4484-2018-272-279
95. Каратеев АЕ, Насонов ЕЛ, Ивашкин ВТ, Мартынов АИ, Яхно НН, Арутюнов ГП, и др. Рациональное использование нестероидных противовоспалительных препаратов. Клинические рекомендации. Научно-практическая ревматология. 2018;56:129. [Karateev AE, Nasonov EL, Ivashkin VT, Martynov AI, Yakhno NN, Arutyunov GP, et al. Rational use of nonsteroidal anti-inflammatory drugs. Clinical guidelines. Nauchcno-Prakticheskaya Revmatologia = Rheumatology Science and Practice. 2018;56:1-29 (In Russ.)]. doi: 10.14412/1995-4484-2018-1-29

96. Каратеев АЕ. Проект национальных клинических рекомендаций (основные положения). Рациональное использование нестроидных противовоспалительных препаратов. (По результатам совещания группы экспертов, Москва, 01.04.2017). Научно-практическая ревматология. 2017;55(4):452-456. [Karateev AE. Draft national clinical guidelines (general provisions). Rational use of nonsteroidal anti-inflammatory drugs. According to the results of the expert group meeting, Moscow, 01.04.2017. Nauchcno-Prakticheskaya Revmatologia $=$ Rheumatology Science and Practice. 2017;55(4):452-456 (In Russ.)]. doi: 10.14412/1995-4484-2017-452-456

97. Насонов ЕЛ, Яхно НН, Каратеев АЕ, Алексеева ЛИ, Баринов АН, Барулин АЕ, и др. Общие принципы лечения скелетно-мышечной боли: междисциплинарный консенсус. Научно-практическая ревматология. 2016;54(3):247-265. [Nasonov EL, Yakhno NN, Karateev AE, Alekseeva LI, Barinov AN, Barulin AE, et al. General principles of treatment for musculoskeletal pain: Interdisciplinary consensus. Nauchcno-

Prakticheskaya Revmatologia $=$ Rheumatology Science and Practice. 2016;54(3):247-265 (In Russ.)]. doi: 10.14412/1995-4484-2016-247-265

98. Насонов ЕЛ. Биоаналоги в ревматологии. Научнопрактическая ревматология. 2016;54(6):628-640. [Nasonov EL. Biosimilars in rheumatology. NauchcnoPrakticheskaya Revmatologia $=$ Rheumatology Science and Practice. 2016;54(6):628-640 (In Russ.)]. doi: 10.14412/1995-4484-2016-628-640

99. Насонов ЕЛ, Олюнин ЮА, Лила АМ. Ревматоидный артрит: проблемы ремиссии и резистентности к терапии. Научно-практическая ревматология.

2018;56(3):263-271. [Nasonov EL, Olyunin YuA, Lila AM. Rheumatoid arthritis: The problems of remission and therapy resistance. Nauchcno-Prakticheskaya Revmatologia $=$ Rheumatology Science and Practice. 2018;56(3):263-271 (In Russ.)]. doi: 10.14412/1995-4484-2018-263-271

100. Насонов ЕЛ. Проблемы иммунопатологии ревматоидного артрита: эволюция болезни. Научнопрактическая ревматология. 2017;55(3):277-294. [Nasonov EL. Problems of rheumatoid arthritis immunopathology: Evolution of the disease. NauchcnoPrakticheskaya Revmatologia $=$ Rheumatology Science and Practice. 2017;55(3):277-294 (In Russ.)]. doi: 10.14412/1995-4484-2017-277-294

101. Каратеев ДЕ, Лучихина ЕЛ, Демидова НВ, Гриднева ГС, Лукина ГВ, Канонирова МА, и др. Применение подкожной формы метотрексата для лечения больных активным ревматоидным артритом (исследование РЕМАРКА). Научно-практическая ревматология. 2016;54(2):138-144. [Karateev DE, Luchikhina EL, Demidova NV, Gridneva GS, Lukina GV, Kanonirova MA, et al. Use of subcutaneous methotrexate for the treatment of patients with active rheumatoid arthritis: The REMARCA trial. Nauchcno-Prakticheskaya Revmatologia = Rheumatology Science and Practice. 2016;54(2):138-144 (In Russ.)]. doi: 10.14412/1995-4484-2016-138-144

102. Каратеев ДЕ, Лучихина ЕЛ, Муравьев ЮВ, Демидова НВ, Гриднева ГС, Новикова ДС, и др. 
Первое российское стратегическое исследование фармакотерапии ревматоидного артрита (РЕМАРКА). Научно-практическая ревматология. 2013;51(2):117125. [Karateev DE, Luchikhina EL, Muravyev YuV, Demidova NV, Gridneva GI, Novikova DS, et al. The first Russian strategic study of pharmacotherapy for rheumatoid arthritis (REMARCA). Nauchcno-Prakticheskaya Revmatologia $=$ Rheumatology Science and Practice. 2013;51(2):117-125 (In Russ.)]. doi: 10.14412/1995-44842013-637

103. Каратеев ДЕ, Лучихина ЕЛ, Демидова НВ, Гриднева ГС, Канонирова МА, Муравьев ЮВ, и др. Первое российское стратегическое исследование фармакотерапии ревматоидного артрита (РЕМАРКА): результаты лечения 130 больных в течение 12 месяцев. Научно-практическая ревматология. 2014;52(6):607614. [Karateev DE, Luchikhina EL, Demidova NV, Gridneva GS, Kanonirova MA, Muravyev YuV, et al. The first Russian strategic study of pharmacotherapy for rheumatoid arthritis (REMARCA trial): Results of 12-month treatment in 130 patients. NauchcnoPrakticheskaya Revmatologia $=$ Rheumatology Science and Practice. 2014;52(6):607-614 (In Russ.)]. doi: 10.14412/1995-4484-2014-607-614

104. Buch MH, Eyre S, McGonagle D. Persistent inflammatory and non-inflammatory mechanisms in refractory rheumatoid arthritis. Nat Rev Rheumatol. 2021;17(1):17-33. doi: 10.1038/s41584-020-00541-7

105. Nagy G, Roodenrijs NMT, Welsing PM, Kedves M, Hamar A, van der Goes MC, et al. EULAR definition of difficult-to-treat rheumatoid arthritis. Ann Rheum Dis. 2021;80(1):31-35. doi: 10.1136/annrheumdis-2020-217344

106. Филатова ЕС, Каратеев АЕ, Лила АМ, Насонов ЕЛ. Функциональная магнитно-резонансная томография при хронической боли у пациентов с ревматическими заболеваниями. Научно-практическая ревматология. 2019;57(6):612-617. [Filatova ES, Karateev AE, Lila AM, Nasonov EL. Functional magnetic resonance imaging for chronic pain in patients with rheumatic diseases. Nauchcno-Prakticheskaya Revmatologia = Rheumatology Science and Practice. 2019;57(6):612-617 (In Russ.)]. doi: 10.14412/1995-4484-2019-612-617

107. Коршунов НИ, Курыгин АГ, Речкина ЕВ, Филатова ЮС, Яльцева НВ. Ревматоидный артрит как психосоматическое заболевание. Научнопрактическая ревматология. 2015;53(5):469-471. [Korshunov NI, Kurygin AG, Rechkina EV, Filatova YuS, Yaltseva NV. Rheumatoid arthritis as a psychosomatic disease. Nauchcno-Prakticheskaya Revmatologia $=$ Rheumatology Science and Practice. 2015;53(5):469-471 (In Russ.)]. doi: 10.14412/1995-4484-2015-469-471

108. Каратеев АЕ, Каратеев ДЕ, Давыдов ОС. Боль и воспаление. Часть 1. Патогенетические аспекты. Научнопрактическая ревматология. 2016;54(6):693-704. [Karateev AE, Karateev DE, Davydov OS. Pain and inflammation. Part 1. Pathogenetic aspects. NauchcnoPrakticheskaya Revmatologia $=$ Rheumatology Science and Practice. 2016;54(6):693-704 (In Russ.)]. doi: 10.14412/1995-4484-2016-693-704

109. Каратеев АЕ, Каратеев ДЕ, Давыдов ОС. Боль и воспаление. Часть 2. Анальгетический потенциал противовоспалительных препаратов. Научно-практическая ревматология. 2017;55(1):58-67. [Karateev AE, Karateev DE, Davydov OS. Pain and inflammation. Part 2. The analgesic potential of anti-inflammatory drugs. Nauchcno-Prakticheskaya Revmatologia = Rheumatology Science and Practice. 2017;55(1):58-67 (In Russ.)]. doi: 10.14412/1995-4484-2017-58-67

110. Каратеев АЕ, Насонов ЕЛ. Хроническая боль и центральная сенситизация при иммуновоспалительных ревматических заболеваниях: патогенез, клинические проявления, возможность применения таргетных базисных противовоспалительных препаратов. Научно-практическая ревматология. 2019;57(2):197209. [Karateev AE, Nasonov EL. Chronic pain and central sensitization in immuno-inflammatory rheumatic diseases: pathogenesis, clinical manifestations, the possibility of using targeted disease modifying antirheumatic drugs. Nauchcno-Prakticheskaya Revmatologia = Rheumatology Science and Practice. 2019;57(2):197-209 (In Russ.)]. doi: 10.14412/1995-4484-2019-197-209

111. Лисицына ТА, Вельтищев ДЮ, Серавина ОФ, Ковалевская ОВ, Зелтынь АЕ, Новиков АА, и др. Провоспалительные цитокины и депрессия при ревматоидном артрите. Научно-практическая ревматология. 2013;51(3):261-266. [Lisitsyna TA, Veltishchev DYu, Seravina OF, Kovalevskaya OB, Zeltyn AE, Novikov AA, et al. Proinflammatory cytokines and depression in rheumatoid arthritis. Nauchcno-Prakticheskaya Revmatologia $=$ Rheumatology Science and Practice. 2013;51(3):261-266 (In Russ.)]. doi: 10.14412/1995-4484-2013-1498

112. Абрамкин АА. Влияние коморбидных психических расстройств на эффективность терапии у больных ревматоидным артритом. Научно-практическая ревматология. 2016;54(3):339-345. [Abramkin AA. Impact of comorbid mental disorders on the efficiency of therapy in patients with rheumatoid arthritis. NauchcnoPrakticheskaya Revmatologia $=$ Rheumatology Science and Practice. 2016;54(3):339-345 (In Russ.)]. doi: 10.14412/1995-4484-2016-339-345

113. Абрамкин АА, Лисицына ТА, Вельтищев ДЮ, Серавина ОФ, Ковалевская ОБ, Насонов ЕЛ. Влияние синтетических базисных противовоспалительных препаратов, генно-инженерных биологических препаратов и психофармакологической терапии на динамику психических расстройств у больных ревматоидным артритом. Научно-практическая ревматология. 2017;55(4):393-402. [Abramkin AA, Lisitsyna TA, Veltishchev DYu, Seravina OF, Kovalevskaya OB, Nasonov EL. Effects of synthetic disease-modifying antirheumatic drugs, biological agents, and psychopharmacotherapy on the mental disorders in patients with rheumatoid arthritis. Nauchcno-Prakticheskaya Revmatologia $=$ Rheumatology Science and Practice. 2017;55(4):393-402 (In Russ.)]. doi: 10.14412/1995-4484-2017-393-402

114. Соловьев СК, Асеева ЕА, Попкова ТВ, Лила АМ, Мазуров ВИ, Насонов ЕЛ. Системная красная волчанка: новые горизонты диагностики и терапии. Научно-практическая ревматология. 2020;58(1):5-14. [Solovyev SK, Aseeva EA, Popkova TV, Lila AM, Mazurov VI, Nasonov EL. Systemic lupus erythematosus: new horizons for diagnosis and therapy. Nauchcno-Prakticheskaya Revmatologia $=$ Rheumatology Science and Practice. 2020;58(1):5-14 (In Russ.)]. doi: 10.14412/1995-4484-2020-5-14

115. Меснянкина АА. Клеточные и молекулярные биомаркеры и потенциальные терапевтические мишени при системной красной волчанке. Научно-практическая ревматология. 2016;54(2):206-218. [Mesnyankina AA. Cellular and molecular biomarkers and potential therapeutic targets in systemic lupus erythematosus. NauchcnoPrakticheskaya Revmatologia = Rheumatology Science and Practice. 2016;54(2):206-218 (In Russ.)]. doi: 10.14412/1995-4484-2016-206-218

116. Асеева ЕА, Соловьев СК, Меснянкина АА, Решетняк ТМ, Лопатина НЕ, Глухова СИ, и др. Результаты наблюдательного проспективного исследования эффективности и безопасности белимумаба (Бенлисты ${ }^{\circledR}$ ) при системной красной волчанке в реальной клинической практике. Научно-практи- 
ческая ревматология. 2016;54(1):31-37. [Aseeva EA, Soloviev SK, Mesnyankina AA, Reshetnyak TM, Lopatina NE, Glukhova SI, et al. Results of an observational prospective study of the efficacy and safety of belimumab (Benlysta ${ }^{\circledR}$ ) in systemic lupus erythematosus in real clinical practice. Nauchcno-Prakticheskaya Revmatologia $=$ Rheumatology Science and Practice. 2016;54(1):31-37 (In Russ.)]. doi: 10.14412/1995-4484-2016-31-37

117. Асеева ЕА, Соловьев СК, Меснянкина АА, Цанян МЭ, Насонов ЕЛ. Опыт применения белимумаба у больных системной красной волчанкой. Научно-практическая ревматология. 2015;53(3):329335. [Aseeva EA, Soloviev SK, Mesnyankina AA, Tsanyan ME, Nasonov EL. Experience with belimumab in patients with systemic lupus erythematosus. NauchcnoPrakticheskaya Revmatologia $=$ Rheumatology Science and Practice. 2015;53(3):329-335 (In Russ.)]. doi: 10.14412/1995-4484-2015-329-335

118. Меснянкина АА, Соловьев СК, Александрова ЕН, Алексанкин АП, Асеева ЕА, Насонов ЕЛ. Двойная терапия генно-инженерными биологическими препаратами у пациентов с системной красной волчанкой. Научно-практическая ревматология. 2016;54(3):281288. [Mesnyankina AA, Solovyev SK, Aleksandrova EN, Aleksankin AP, Aseeva EA, Nasonov EL. Dual therapy with biologicals in patients with systemic lupus erythematosus. Nauchcno-Prakticheskaya Revmatologia = Rheumatology Science and Practice. 2016;54(3):281-288 (In Russ.)]. doi: 10.14412/1995-4484-2016-281-288

119. Меснянкина АA, Соловьев СК, Асеева ЕА, Насонов ЕЛ. Эффективность генно-инженерной биологической терапии и особенности гуморального иммунитета у больных системной красной волчанкой. Научно-практическая ревматология. 2018;56(3):302309. [Mesnyankina AA, Solovyev SK, Aseeva EA, Nasonov EL. The efficiency of biological therapy and the features of humoral immunity in patients with systemic lupus erythematosus. Nauchcno-Prakticheskaya Revmatologia $=$ Rheumatology Science and Practice. 2018;56(3):302-309 (In Russ.)]. doi: 10.14412/1995-44842018-302-309

120. Насонов ЕЛ, Мазуров ВИ, Зонова ЕВ, Князева ЛА, Марусенко ИМ, Несмеянова ОБ, и др.

Эффективность и безопасность биоаналога ритуксимаба (Ацеллбия®) при ревматоидном артрите в качестве «первого» генно-инженерного биологического препарата: результаты клинического исследования III фазы (ALTERRA). Научно-практическая ревматология. 2017;55(4):351-359. [Nasonov EL, Mazurov VI, Zonova EV, Knyazeva LA, Marusenko IM,

Nesmeyanova OB, et al. The efficacy and safety of rituximab biosimilar (Acellbia $\AA$ ) in rheumatoid arthritis as the first biological agent: Results of phase III (ALTERRA) clinical trial. Nauchcno-Prakticheskaya Revmatologia $=$ Rheumatology Science and Practice. 2017;55(4):351-359 (In Russ.)]. doi: 10.14412/1995-4484-2017-351-359

121. Насонов ЕЛ, Зонова ЕВ, Иванова ОН, Князева ЛА, Мазуров ВИ, Самигуллина РР, и др. Результаты сравнительного клинического исследования III фазы препаратов ритуксимаба (Ацеллбия® и Мабтера $\left.{ }^{\circledR}\right)$ при ревматоидном артрите (исследование BIORA). Научно-практическая ревматология. 2016;54(5):510519. [Nasonov EL, Zonova EV, Ivanova ON, Knyazeva LA, Mazurov VI, Samigullina RR, et al. The results of a phase III comparative clinical trial of rituximab (Acellbia ${ }^{\circledR}$ and Mabthera ${ }^{\circledR}$ ) in rheumatoid arthritis (the BIORA study). Nauchcno-Prakticheskaya Revmatologia $=$ Rheumatology Science and Practice. 2016;54(5):510-519 (In Russ.)]. doi: 10.14412/1995-44842016-510-519
122. Королев МА, Убшаева ЮБ, Банщикова НЕ, Летягина ЕА, Муллагалиев АА. Результаты исследования эффективности и безопасности немедицинского переключения с оригинального препарата ритуксимаб на биоаналог у пациентов с ревматоидным артритом (исследование АМБИРА). Научно-практическая ревматология. 2020;58(6):663-672. [Korolev MA, Ubshaeva YuB, Banshchikova NY, Letyagina EA, Mullagaliev AA. The results of investigating the efficacy and safety of non-medical switching from the original rituximab to its biosimilar in rheumatoid arthritis patients (AMBIRA study). Nauchcno-Prakticheskaya Revmatologia $=$ Rheumatology Science and Practice. 2020;58(6):663-672 (In Russ.)]. doi: 10.47360/1995-44842020-663-672

123. Кусевич ДА, Авдеева АС, Рыбакова ВВ, Чичасова НВ, Насонов ЕЛ. Клиническая эффективность биоаналога ритуксимаба (Ацеллбии $\left.{ }^{\circledR}\right)$ в дозе 600 мг у больных с активным ревматоидным артритом в клинической практике. Научно-практическая ревматология. 2018;56(6):703-708. [Kusevich DA, Avdeeva AS, Rybakova VV, Chichasova NV, Nasonov EL. Clinical efficacy of the rituximab biosimilar Acellbia ${ }^{\circledR} 600 \mathrm{mg}$ in patients with active rheumatoid arthritis in clinical practice. Nauchcno-Prakticheskaya Revmatologia $=$ Rheumatology Science and Practice. 2018;56(6):703-708 (In Russ.)]. doi: 10.14412/1995-4484-2018-703-708

124. Авдеева АС, Артюхов АС, Дашинимаев ЭБ, Черкасова МВ, Насонов ЕЛ. Динамика показателей цитокинового профиля на фоне применения биоаналога ритуксимаба (Ацеллбия, «БИОКАД») и оригинального препарата (Мабтера, «Ф. ХоффманнЛя Рош» Лтд., Швейцария) в терапии ревматоидного артрита. Научно-практическая ревматология. 2019;57(1):46-55. [Avdeeva AS, Artyukhov AS, Dashinimaeva EB, Cherkasova MV, Nasonov EL. Changes of cytokine profile measures during the treatment of rheumatoid arthritis with rituximab biosimilar (Acellbia, BIOCAD) and the original drug (MabThera, F. Hoffmann-La Roche Ltd., Switzerland). NauchcnoPrakticheskaya Revmatologia $=$ Rheumatology Science and Practice. 2019;57(1):46-55 (In Russ.)]. doi: 10.14412/1995-4484-2019-46-55

125. Авдеева АС, Черкасова МВ, Кусевич ДА, Рыбакова ВВ, Насонов ЕЛ. Иммунологические эффекты биоаналога ритуксимаба (Ацеллбия, «БИОКАД») у больных ревматоидным артритом. Научно-практическая ревматология. 2018;56(5):556563. [Avdeeva AS, Cherkasova MV, Kusevich DA, Rybakova VV, Nasonov EL. Immunological effects of a rituximab biosimilar (Acelbia, BIOCAD) in patients with rheumatoid arthritis. Nauchcno-Prakticheskaya Revmatologia $=$ Rheumatology Science and Practice. 2018;56(5):556-563 (In Russ.)]. doi: 10.14412/1995-44842018-556-563

126. Коротаева ТВ, Мазуров ВИ, Лила АМ, Гайдукова ИЗ, Бакулев АЛ, Самцов АВ, и др. Эффективность и безопасность нетакимаба у пациентов с псориатическим артритом: результаты клинического исследования III фазы PATERA. Научно-практическая ревматология. 2020;58(5):480-488. [Korotaeva TV, Mazurov VI,

Lila AM, Gaydukova IZ, Bakulev AL, Samtsov AV, et al. Efficacy and safety of netakimab in patients with psoriatic arthritis: results of the phase III PATERA clinical study. Nauchcno-Prakticheskaya Revmatologia = Rheumatology Science and Practice. 2020;58(5):480-488 (In Russ.)]. doi: 10.47360/1995-4484-2020-480-488

127. Мазуров ВИ, Гайдукова ИЗ, Эрдес Ш, Дубинина ТВ, Пристром АМ, Кундер ЕВ, и др. Эффективность и безопасность нетакимаба, моноклонального антите- 
ла против интерлейкина-17А, у пациентов с активным анкилозирующим спондилитом. Результаты международного многоцентрового рандомизированного двойного слепого клинического исследования III фазы BCD-085-5/ASTERA. Научно-практическая ревматология. 2020;58(4):376-386. [Mazurov VI, Gaydukova IZ, Erdes S, Dubinina TV, Pristrom AM, Kunder EV, et al. Efficacy and safety of netakimab, anti-IL-17A monoclonal antibody, in patients with ankylosing spondylitis. Results of phase III international, multicenter, randomized double-blind clinical trial BCD-085-5/ASTERA. NauchcnoPrakticheskaya Revmatologia $=$ Rheumatology Science and Practice. 2020;58(4):376-386 (In Russ.)]. doi: 10.47360/1995-4484-2020-376-386

128. Лила АМ, Мазуров ВИ, Зонова ЕВ, Несмеянова ОБ, Плаксина ТВ, Кречикова ДГ, и др. Сравнительная оценка долгосрочной эффективности и безопасности биоаналога инфликсимаба BCD-055 и референтного инфликсимаба у пациентов с анкилозирующим спондилитом: результаты международного многоцентрового рандомизированного двойного слепого клинического исследования III фазы ASART-2. Научнопрактическая ревматология. 2018;56(3):293-301. [Lila AM, Mazurov VI, Zonova EV, Nesmeyanova OB, Plaksina TV, Krechikova DG, et al. Comparative evaluation of the long-term efficacy and safety of the infliximab biosimilar BCD-055 and reference infliximab in patients with ankylosing spondylitis: Results of the international multicenter randomized double-blind phase III clinical study ASART-2. Nauchcno-Prakticheskaya Revmatologia = Rheumatology Science and Practice. 2018;56(3):293-301 (In Russ.)]. doi: 10.14412/1995-4484-2018-293-301

129. Насонов ЕЛ, Лисицына ТА, Зонова ЕВ, Кузькина СМ. Влияние олокизумаба на исходы, оцениваемые пациентом с ревматоидным артритом: результаты двойного слепого рандомизированного плацебо-контролируемого многоцентрового исследования III фазы (CREDO 1). Научно-практическая ревматология. 2021;59(1):62-69. [Nasonov EL, Lisitsyna TA, Zonova EV, Kuzkina SM. The effect of olokizumab on rheumatoid arthritis patient's reported outcomes: results of a double-blind randomized placebo-controlled multicenter phase III trial (CREDO 1). Nauchcno-Prakticheskaya Revmatologia = Rheumatology Science and Practice. 2021;59(1):62-69 (In Russ.)]. doi: 10.47360/1995-4484-2021-62-69

130. Nasonov E, Fatenejad S, Feist E, Ivanova M, Korneva E, Krechikova DG, et al. Olokizumab, a monoclonal antibody against interleukin 6 , in combination with methotrexate in patients with rheumatoid arthritis inadequately controlled by methotrexate: Efficacy and safety results of a randomised controlled phase III study. Ann Rheum Dis. 2021 Aug 3:annrheumdis-2021-219876. doi: 10.1136/ annrheumdis-2021-219876

131. Takeuchi T, Tanaka Y, Yamanaka H, Amano K, Nagamine R, Park W, et al. Efficacy and safety of olokizumab in Asian patients with moderate-to-severe rheumatoid arthritis, previously exposed to anti-TNF therapy: Results from a randomized phase II trial. Mod Rheumatol. 2016;26(1):15-23. doi: 10.3109/14397595.2015.1074648

132. Genovese MC, Fleischmann R, Furst D, Janssen N, Carter J, Dasgupta B, et al. Efficacy and safety of olokizumab in patients with rheumatoid arthritis with an inadequate response to TNF inhibitor therapy: Outcomes of a randomised phase IIb study. Ann Rheum Dis. 2014;73(9):1607-1615. doi: 10.1136/annrheumdis-2013-204760

133. Genovese MC, Durez P, Fleischmann R, Tanaka Y, Furst D, Yamanaka H, et al. Long-term safety and efficacy of olokizumab in patients with rheumatoid arthritis and inadequate response to tumor necrosis factor inhibitor therapy in phase II studies. Eur J Rheumatol. 2021 Jun 4. doi: 10.5152/eurjrheum.2021.19207

134. Коротаева ТВ, Зоткин ЕГ, Несмеянова ОБ, Везикова НН, Ершова ОБ, Измозжерова НВ, и др. Применение ингибитора интерлейкина-17А секукинумаба при псориатическом артрите. Субанализ российской популяции международных рандомизированных клинических исследований FUTURE 1 и FUTURE 2. Научно-практическая ревматология. 2017;55(2):151-158. [Korotaeva TV, Zotkin EG, Nesmeyanova OB, Vezikova NN, Ershova OB, Izmozzherova NV, et al. Use of the interleukin-17A inhibitor secukinumab in psoriatic arthritis: A subanalysis of the Russian population in the international randomized clinical trials FUTURE 1 and FUTURE 2. NauchcnoPrakticheskaya Revmatologia $=$ Rheumatology Science and Practice. 2017;55(2):151-158 (In Russ.)]. doi: 10.14412/1995-4484-2017-151-158

135. Эрдес ШФ, Денисов ЛН, Маслянский АЛ, Ершова ОБ, Станислав МЛ, Сальникова ТС, и др. Моноклональные антитела к интерлейкину 17 для лечения анкилозирующего спондилита: результаты анализа российской группы больных из рандомизированных двойных слепых плацебоконтролируемых исследований MEASURE 1 и MEASURE 2. Научнопрактическая ревматология. 2017;55(1):17-25.

[Erdes SF, Denisov LN, Maslyansky AL, Ershova OB, Stanislav ML, Salnikova TS, et al. Anti-interleukin-17 monoclonal antibody for the treatment of ankylosing spondylitis: Results of analysis of a Russian patient group from the randomized, double-blind, placebo-controlled MEASURE 1 and MEASURE 2 trials. NauchcnoPrakticheskaya Revmatologia = Rheumatology Science and Practice. 2017;55(1):17-25 (In Russ.)]. doi: 10.14412/19954484-2017-17-25

136. Насонов ЕЛ, Станислав МЛ, Раскина ТА, Куропаткин ГВ, Ширинский ИВ, Ребров АП, и др. Эффективность и безопасность сарилумаба в комбинации с метотрексатом у пациентов с активным ревматоидным артритом и неадекватным эффектом монотерапии метотрексатом (результаты исследования III фазы по протоколу MOBILITY). Научнопрактическая ревматология. 2019;57(2):142-148. [Nasonov EL, Stanislav ML, Raskina TA, Kuropatkin GV, Shirinsky IV, Rebrov AP, et al. Efficacy and safety of sarilumab in combination with methotrexate in patients with active rheumatoid arthritis and inadequate effect of methotrexate monotherapy (results of phase III MOBILITY study). Nauchcno-Prakticheskaya Revmatologia $=$ Rheumatology Science and Practice. 2019;57(2):142-148 (In Russ.)]. doi: 10.14412/1995-44842019-142-148

137. Насонов ЕЛ. Коронавирусная болезнь 2019 (COVID19): размышления ревматолога. Научно-практическая ревматология. 2020;58(2):123-132. [Nasonov EL. Coronavirus disease 2019 (COVID-19): A rheumatologist's thoughts. Nauchcno-Prakticheskaya Revmatologia $=$ Rheumatology Science and Practice. 2020;58(2):123-132 (In Russ.)]. doi: 10.14412/1995-4484-2020-123-132

138. Насонов ЕЛ, Бекетова ТВ, Решетняк ТМ, Лила АМ, Ананьева ЛП, Лисицина ТА, и др. Коронавирусная болезнь 2019 (COVID-19) и иммуновоспалительные ревматические заболевания: на перекрестке проблем тромбовоспаления и аутоиммунитета. Научнопрактическая ревматология. 2020;58(4):353-367. [Nasonov EL, Beketova TV, Reshetnyak TM, Lila AM, Ananieva LP, Lisitsyna TA, et al. Coronavirus disease 2019 (COVID-19) and immune-mediated inflammatory rheumatic diseases: At the crossroads of thromboinflammation 
and autoimmunity. Nauchcno-Prakticheskaya Revmatologia = Rheumatology Science and Practice. 2020;58(4):353-367 (In Russ.)]. doi: 10.47360/1995-4484-2020-353-367

139. Насонов ЕЛ. Коронавирусная болезнь 2019 (COVID-19) и аутоиммунитет. Научно-практическая ревматология. 2021;59(1):5-30. [Nasonov EL. Coronavirus disease 2019 (COVID-19) and autoimmunity. Nauchcno-Prakticheskaya Revmatologia = Rheumatology Science and Practice. 2021;59(1):5-30 (In Russ.)]. doi: 10.47360/1995-4484-2021-5-30

140. Насонов ЕЛ, Попкова ТВ, Панафидина ТА. Проблемы ранней системной красной волчанки в период пандемии COVID-19. Научно-практическая ревматология. 2021;59(2):119-128. [Nasonov EL, Popkova TV, Panafidina TA. Problems of early diagnosis of systemic lupus erythematosus during the COVID-19 pandemic. Nauchcno-Prakticheskaya Revmatologia $=$ Rheumatology Science and Practice. 2021;59(2):119-128 (In Russ.)]. doi: 10.47360/1995-4484-2021-119-128

141. Лесняк ОМ, Гладкова ЕН, Зоткина КЕ, Григорьева АЛ, Сафонова ЮА, Кузнецова ОЮ, и др. Коронавирусная болезнь 19 (COVID-19) и остеопороз: проблемы ведения пациентов и влияние терапии остеопороза на частоту развития клинически манифестной инфекции. Научно-практическая ревматология. 2021;59(3):263-268. [Lesnyak OM, Gladkova EN, Zotkina KE, Grigoryeva AL, Safonova YuA, Kuznetsova OYu, et al. Problems in patient management and the impact of osteoporosis therapy on the incidence of clinical infection. Nauchcno-Prakticheskaya Revmatologia $=$ Rheumatology Science and Practice. 2021;59(3):263-268 (In Russ.)]. doi: 10.47360/1995-44842021-263-268

142. Борисова АБ, Лисицына ТА, Вельтищев ДЮ, Насонов ЕЛ. Скрининг тревоги, депрессии и стрессовой напряженности у больных ревматическими и мышечно-скелетными заболеваниями в начале пандемии коронавирусной болезни 2019 (COVID-19). Научно-практическая ревматология. 2021;59(6):676683. [Borisova AB, Lisitsyna TA, Veltishchev DYu, Nasonov EL. Anxiety, depression and stress tension screening in patients with rheumatic and musculoskeletal diseases at the onset of the 2019 coronavirus disease (COVID-19) pandemic. Nauchcno-Prakticheskaya Revmatologia = Rheumatology Science and Practice. 2021;59(6):676-683 (In Russ.)]. doi: 10.47360/1995-44842021-676-683

143. Белов БС, Лила AM. COVID-19 и ревматология: год спустя. Научно-практическая ревматология. 2021;59(1):31-36. [Belov BS, Lila AM. COVID-19 and rheumatology: A year later. Nauchcno-Prakticheskaya Revmatologia $=$ Rheumatology Science and Practice. 2021;59(1):31-36 (In Russ.)]. doi: 10.47360/1995-44842021-31-36

144. Каратеев АЕ, Амирджанова ВН, Насонов ЕЛ, Лила АМ, Алексеева ЛИ, Погожева ЕЮ, и др. «Постковидный синдром»: в центре внимания скелетно-мышечная боль. Научно-практическая ревматология. 2021;59(3):255-262. [Karateev AE,

Насонов Е.Л. ORCID: https://orcid.org/000-002-1598-8360

Лила A.M. ORCID: https://orcid.org/0000-0002-6068-3080

Дубинина T.B. ORCID: https://orcid.org/0000-0002-1771-6246

Никитинская 0.A. ORCID: https://orcid.org/0000-0001-6759-8367

Амирджанова B.H. ORCID: https://orcid.org/0000-0001-5382-6357
Amirdzhanova VN, Nasonov EL, Lila AM, Alekseeva LI, Pogozheva EYu, et al. "Post-COVID syndrome": The focus is on musculoskeletal pain. NauchcnoPrakticheskaya Revmatologia $=$ Rheumatology Science and Practice. 2021;59(3):255-262 (In Russ.)]. doi: 10.47360/1995-4484-2021-255-262

145. Бекетова ТВ, Бланк ЛМ, Лила AM. COVID-19 у пациентки с АНЦА-ассоциированным системным васкулитом, получавшей анти-В-клеточную терапию ритуксимабом. Научно-практическая ревматология. 2020;58(4):456-462. [Beketova TV, Blank LM, Lila AM. COVID-19 in a patient with ANCA-associated systemic vasculitis, receiving anti-B cell therapy (rituximab). Nauchcno-Prakticheskaya Revmatologia = Rheumatology Science and Practice. 2020;58(4):456-462 (In Russ.)]. doi: 10.47360/1995-4484-2020-456-462

146. Каледа МИ, Никишина ИП, Федоров ЕС, Насонов ЕЛ. Коронавирусная болезнь 2019 (COVID-19) у детей: уроки педиатрической ревматологии. Научно-практическая ревматология. 2020;58(5):469-479. [Kaleda MI, Nikishina IP, Fedorov ES, Nasonov EL. Coronavirus disease 2019 (COVID-19) in children: Lessons from pediatric rheumatology. Nauchcno-Prakticheskaya Revmatologia $=$ Rheumatology Science and Practice. 2020;58(5):469-479 (In Russ.)]. doi: 10.47360/1995-4484-2020-469-479

147. Каратеев АЕ, Насонов ЕЛ, Лила АМ. Вызывают ли нестероидные противовоспалительные препараты специфические осложнения при коронавирусной инфекции COVID-19? Научно-практическая ревматология. 2020;58(3):340-343. [Karateev AE, Nasonov EL, Lila AM. Do NSAIDs cause specific complications in COVID-19 coronavirus infection? NauchcnoPrakticheskaya Revmatologia $=$ Rheumatology Science and Practice. 2020;58(3):340-343 (In Russ.)]. doi: 10.14412/1995-4484-2020-340-343

148. Насонов ЕЛ, Белов БС, Лила АМ, Аронова ЕС, Гриднева ГИ, Кудрявцева АВ, и др. Течение и исходы COVID-19 у пациентов с иммуновоспалительными ревматическими заболеваниями: предварительные данные регистра НИИР/APP-COVID-19 и обзор литературы. Научно-практическая ревматология. 2021;59(6):666-675. [Nasonov EL, Belov BS, Lila AM, Aronova ES, Gridneva GI, Kudryavtseva AV, et al. Course and outcomes of COVID-19 in patients with immunoinflammatory rheumatic diseases: Preliminary data from the NIIR/APP-COVID-19 registry and literature review. Nauchcno-Prakticheskaya Revmatologia $=$ Rheumatology Science and Practice. 2021;59(6):666-675 (In Russ.)]. doi: 10.47360/19954484-2021-666-675

149. Белов БС, Лила АМ, Насонов ЕЛ. Вакцинация против SARS-CoV-2 при ревматических заболеваниях: вопросы безопасности. Научно-практическая ревматология. 2022. Принята к печати. [Belov BS, Lila AM, Nasonov EL. Vaccination against SARS-CoV-2 in rheumatic diseases: Safety issues. NauchcnoPrakticheskaya Revmatologia = Rheumatology Science and Practice. 2022. Accepted for publication (In Russ.)]. 